\title{
Butterfly species diversity and their floral preferences in the Rupa wetland of Nepal
}

\author{
Bandana Subedi ${ }^{1}$, Alyssa Stewart ${ }^{2}$, Bijaya Neupane ${ }^{1}$, Sudha Ghimire ${ }^{1}$, and Hari Adhikari ${ }^{3}$ \\ ${ }^{1}$ Institute of Forestry, Tribhuvan University \\ ${ }^{2}$ Mahidol University Faculty of Science \\ ${ }^{3}$ Helsingin yliopisto
}

August 20, 2020

\begin{abstract}
The diversity of butterflies is known to some extent in Nepal, but the study of their interactions with nectar plant sources and floral attributes is limited. This study was conducted along the periphery of Rupa Wetland, a Ramsar site, from February to November 2019 to assess butterfly species diversity and to identify the factors influencing their foraging choices at nectar plants. We assessed the number of butterfly species, their abundance, and their floral foraging behavior, from 28 linear transects (500 $\mathrm{m}$ long each) placed in a stratified and random manner throughout the study area. Five factors, i.e., category of plant, flower colour, corolla shape, corolla depth, and the proboscis length of butterfly species were taken into account to assess the nectar plant choices of butterfly families. Moreover, species diversity at the family level, and overall, were determined through several indices. When examining overall butterfly diversity and abundance, we recorded a total of 1,535 butterflies belonging to 138 species within six families. For our examination of butterfly-nectar plant observations, we recorded a total of 298 individuals belonging to 31 species of butterfly visiting a total of 28 nectar plant species. Among the recorded butterflies, Zemeros flegyas was found to be the most abundant (92 individuals), while only a single individual each of the species Troides helena, Gandaca herina and Belonois aurota were recorded. Of the 28 nectar host plant species, Biden pilosa was the most popular and was visited by 13 species of butterflies. Overall, total butterfly visitation was found to be significantly influenced by plant category (herbaceous preferred over woody), floral colour (yellow, white, and purple preferred over pink), and corolla shape (tubular preferred over non-tubular). Moreover, there was a significant positive correlation $(r=0.466)$ between the proboscis length of butterflies and the corolla tube length of flowers $(\mathrm{p}<0.001)$.
\end{abstract}

Butterfly species diversity and their floral preferences in the Rupa wetland of Nepal Bandana Subedi ${ }^{*}$, Alyssa B. Stewart ${ }^{2}$, Bijaya Neupane ${ }^{1}$, Sudha Ghimire ${ }^{1}$, Hari Adhikari ${ }^{3}{ }^{*}$

1. Institute of Forestry, Tribhuvan University, Pokhara, Nepal; bandanasubedi84@gmail.com ; bijneu@gmail.com; sudhaghimire999@gmail.com

2. Department of Plant Science, Mahidol University, Bangkok, Thailand 10400; alyssa.ste@mahidol.edu

3. Earth Change Observation Laboratory, Department of Geosciences and Geography, University of Helsinki, Finland; hari.adhikari@helsinki.fi

4. Institute for Atmospheric and Earth System Research, Faculty of Science, University of Helsinki, Finland

*Correspondence: bandanasubedi84@gmail.com; hari.adhikari@helsinki.fi; Tel: +9779869636162; +358449899584 


\begin{abstract}
The diversity of butterflies is known to some extent in Nepal, but the study of their interactions with nectar plant sources and floral attributes is limited. This study was conducted along the periphery of Rupa Wetland, a Ramsar site, from February to November 2019 to assess butterfly species diversity and to identify the factors influencing their foraging choices at nectar plants. We assessed the number of butterfly species, their abundance, and their floral foraging behavior, from 28 linear transects (500 m long each) placed in a stratified and random manner throughout the study area. Five factors, i.e., category of plant, flower colour, corolla shape, corolla depth, and the proboscis length of butterfly species were taken into account to assess the nectar plant choices of butterfly families. Moreover, species diversity at the family level, and overall, were determined through several indices. When examining overall butterfly diversity and abundance, we recorded a total of 1,535 butterflies belonging to 138 species within six families. For our examination of butterflynectar plant observations, we recorded a total of 298 individuals belonging to 31 species of butterfly visiting a total of 28 nectar plant species. Among the recorded butterflies,Zemeros flegyas was found to be the most abundant (92 individuals), while only a single individual each of the species Troides helena, Gandaca herina and Belonois aurotawere recorded. Of the 28 nectar host plant species, Biden pilosawas the most popular and was visited by 13 species of butterflies. Overall, total butterfly visitation was found to be significantly influenced by plant category (herbaceous preferred over woody), floral colour (yellow, white, and purple preferred over pink), and corolla shape (tubular preferred over non-tubular). Moreover, there was a significant positive correlation $(\mathrm{r}=0.466)$ between the proboscis length of butterflies and the corolla tube length of flowers $(\mathrm{p}<0.001)$.
\end{abstract}

Key words : Lepidoptera, nectar plants, species diversity, corolla depth, proboscis length

\title{
Introduction
}

Nepal is remarkably diverse in flora and fauna due to its climatic and topographical variation. The dramatic differences in elevation and microclimate result in a variety of ecosystems, from tropical savannas along the Indian border, to subtropical broad leaf and coniferous forests in the Hilly region, to temperate broadleaf and coniferous forests on the lap of the Himalayas (MoFE, 2018). The land area of Nepal occupies just $0.1 \%$ of global area but comprises $3.2 \%$ of the world's floral diversity and $1.1 \%$ of global faunal diversity (MFSC, 2014).

Insects are one of the key indicators of healthy ecosystems, and they play a significant role in ecosystem functioning (Springett, 1978). Butterflies, one of the best-known pollinators and bio indicators, belong to the order Lepidoptera (suborder Rhopalocera) (Durairaj and Sinha, 2015). Out of around 20,000 species of butterflies recorded worldwide, Nepal is home to 668 species from 263 genera, which is about $4.3 \%$ of globally known species (Smith and Majupuria, 2006; Sajan and Pariyar, 2019; Panthee et al., 2018; Sapkota et al., 2020; Tamang, Nuppa, et al., 2019; Muhammad et al., 2018; Poel et al., 2020). Around 29 species and subspecies of butterflies are endemic to Nepal. These endemic species are disappearing slowly, and about $18 \%$ of the butterfly species found in the mid hill zones are considered threatened (ICIMOD [International Center for Integrated Mountain Development], 2007). A total of 142 species of butterflies found in Nepal are under the IUCN red list category, among which 12 are endangered, 43 are vulnerable, and 87 are susceptible (Paudel, Bhattarai and Kindlmann, 2012). Likewise, three species (Teinopalpus imperialis, Troides aeacus , and Troides helena) are placed under CITES Appendix II (Khanal, Chalise and Solanki, 2013).

Approximately $80 \%$ of known plant species worldwide are angiosperms, and a large percent of these species depend on insect pollination (Ackerman, 2000; Nimbalkar, Chandekar and Khunte, 2011). The immense diversity of pollinators, and plants requiring pollination, has resulted in the evolution of various mechanisms and strategies whereby plants attract specific pollinators to promote intraspecific pollen transfer (Larsson, 2005). Such mechanisms include evolving specific floral shapes (e.g., tubular flowers, or floral landing platforms), varying the sugar concentration in nectar, evolving a time lock mechanism for pollen release, and 
evolving special structures that prevent access to nectar and pollen (Freitas and Sazima, 2003). Essentially, the shape, size, structure and colour of flowers directly influence flower-visiting animals (Ilse, 1928; Erhardt, 1991; Boggs and Ross, 1993). Additionally, butterflies are often constrained in their feeding habits by the length of their mouthparts, as they cannot forage on plant species with corolla tube lengths longer than the length of their proboscis (Cruden and Hermann-Parker, 1979; Porter, 1992).

While insects are known to be critical to ecosystem functioning, the biodiversity of insects is threatened worldwide. There has been a dramatic decline among Lepidopterans that may lead to the extinction of $40 \%$ of species over the next few decades (Sánchez-Bayo and Wyckhuys, 2019). Minor changes in their habitat may lead to either migration or local extinction if the required attention is not given (Kunte, 1997) because many species require specific plants as food or sites for reproduction (Bernays and Graham, 1988). The biggest threat that humans pose to the survival of insects, including butterfly populations, is habitat destruction (New et al., 1995). Due to the rapid increase in global human population size, anthropogenic changes are impacting butterflies through both direct habitat loss as well as the loss of plant species on which butterflies depend (Hoyle and James, 2005). Moreover, butterflies are particularly sensitive to environmental changes (Stefanescu et al ., 2011), including the fast rise of industries, intense use of fertilizers and insecticides, climate change, nitrogen pollution, mono-cropping, forest fires, fragmentation, and habitat degradation, all of which make them vulnerable to extinction. As butterflies are known to be flagship species for insect conservation (Wagner, Nelson and Schweitzer, 2003; Tiple, Deshmukh and Dennis, 2005), any research efforts that target the conservation of butterfly species will automatically save many other species in the area. To protect this flagship group from further population declines, and potential species extinctions, studies examining their diversity, habitat suitability and nectar plant choices are necessary.

While there have been many studies on butterflies from different parts of Nepal (Smith and Majupuria, 2006; Khanal, 2006; Bhusal and Khanal, 2008; Khanal et al., 2013; Khanal et al., 2014; Rai, 2017; Suwal et al., 2019), previous studies have focused on the diversity, taxonomy and distribution of butterflies, and few studies have examined butterfly-plant interactions (Nepali et al., 2018; Shrestha et al., 2020). However, extensive ecological studies to determine the factors that influence butterfly foraging choices are crucial to improve the ecological utility of butterflies and to preserve them as indicator taxa. Given the lack of sufficient knowledge about butterfly diversity and their floral foraging preferences in Nepal, this research aimed to fulfill this gap by addressing two main objectives. The first objective was to examine butterfly diversity and abundance throughout the year at Rupa Wetland. This area is known to support high butterfly diversity (Smith, Sherpa and Shristi, 2016), but we still lack long-term studies (spanning multiple seasons) that quantify the abundance of different species. The second objective was to examine butterfly-nectar plant interactions, and to assess the factors influencing floral foraging choices. The information gained from our two objectives is necessary to conserve both butterflies and their preferred nectar plants in an effective and sustained manner.

\section{Materials and methods}

\subsection{Study Area}

Rupa Wetland (28 8'55"N 84deg6'40"E) (Figure 1), declared a Ramsar site in February 2016, is one of the most important wetlands of Nepal situated in Chitwan Annapurna Landscape at an elevation of $600 \mathrm{~m}$ above sea level (Paudel, Adhikari and Paudel, 2017). The lake serves as a famous tourist destination and also supports fish farming, thus providing a great source of income to local livelihoods (Rajbhandari and Shrestha, 2014). It is the third biggest lake of Pokhara valley with a total watershed area of 3,000 hectares and a lake area of 112 hectares. The lake provides suitable habitat for diverse butterflies, dragonflies, fish species, and some major wetland bird species (Gautam et al >,2019). The wetland is important for migratory birds, and 36 species of water birds have been recorded (Kafle et al. , 2008). This study was conducted in the catchment area of the lake. It constitutes 361 species of vegetation and 175 species of forest medicinal herbs (Dangol, 2015). The watershed area to the east of the wetland is covered with a mixed forest of Chilaune (Schima wallichii) and Katus (Castanopsis indica) with native wild flowers like 
Damaifal (Ardisia solanacea), Marantina's Swan flower (Globba marantina), and Kuro (Bidens Pilosa), thus providing a favorable habitat for butterflies. The western hill slope is covered with a mix of native vegetation and cultivated land, while the northern slope consists of privately owned terraced land for agriculture crops, as well as some floating aquatic vegetation, grasses, and rice fields that are found along the lake shoreline.

\subsection{Data collection}

The study area was fully explored from January to December 2019 throughout Nepal's four seasons: premonsoon (March to May), monsoon (June to September), post monsoon (October to November), and winter (December to February) (GoN, 2011). To address our first objective (assessing butterfly diversity and abundance), we collected data from March to November 2019; data was not collected during the winter due to the lack of butterflies during this season, as they are intolerant to cold temperatures (McDermott Long et $a l>, 2017$ ). To address our second objective (examining butterfly foraging choices), we collected data from February to July 2019, which covered the flowering periods of diverse plant species in the study area.

Data for both objectives was collected using the transect count method described by Pollard (1977). A total of 28 transects, $500 \mathrm{~m}$ long each, were arranged in a stratified and random manner at an interval of $100 \mathrm{~m}$ apart along the lake's edge (i.e., scrubland where maximum butterflies were observed) (Figure 1a). Each transect was walked at a slow, constant pace and all butterflies within $5 \mathrm{~m}$ of the observer walking the transect (to either side, in front, and above) were counted and recorded. Each transect was walked twice per month, resulting in a total of 18 replicates for the butterfly diversity and abundance data, and 12 replicates for the butterfly foraging data. Transect lines were walked in the morning between 8:00 to 12:00 $\mathrm{h}$ on sunny days (avoiding rainy and windy days) so that maximum butterfly species could be spotted (Caldas and Robbins, 2003). Butterflies were identified in the field based on their behavioral and morphological characteristics following Smith and Majupuria (2006) and plants were identified based on leaf, floral, and fruit characteristics following Storrs and Storrs (1990).

Additionally, for data collected on butterfly foraging choices, attempts were made to catch every feeding butterfly seen on each transect by using a sweep net. Proboscis length was determined by restraining the tip of the unfurled proboscis with forceps or a needle and measuring the distance from the base to the tip (Ehrlich and Raven, 1964). Moreover, the flower corolla at which the butterfly was observed was plucked to measure the corolla tube length. Corolla depth was measured from the most convenient point from which a butterfly might place the proboscis to the corolla base, where the nectar was available. For each plant species, we also recorded plant category (herbaceous or woody), flower colour, and corolla shape (tubular or non-tubular). Finally, for the butterfly diversity and abundance data, we used the number of butterfly sightings to categorize each species as very rare ( $<2$ sightings), rare (2-15 sightings) not rare (15-50 sightings), common (50-100 sightings) and very common (>100 sightings) to determine the site-specific status of each butterfly species (Tiple et al., 2005; Shrestha et al., 2018). 

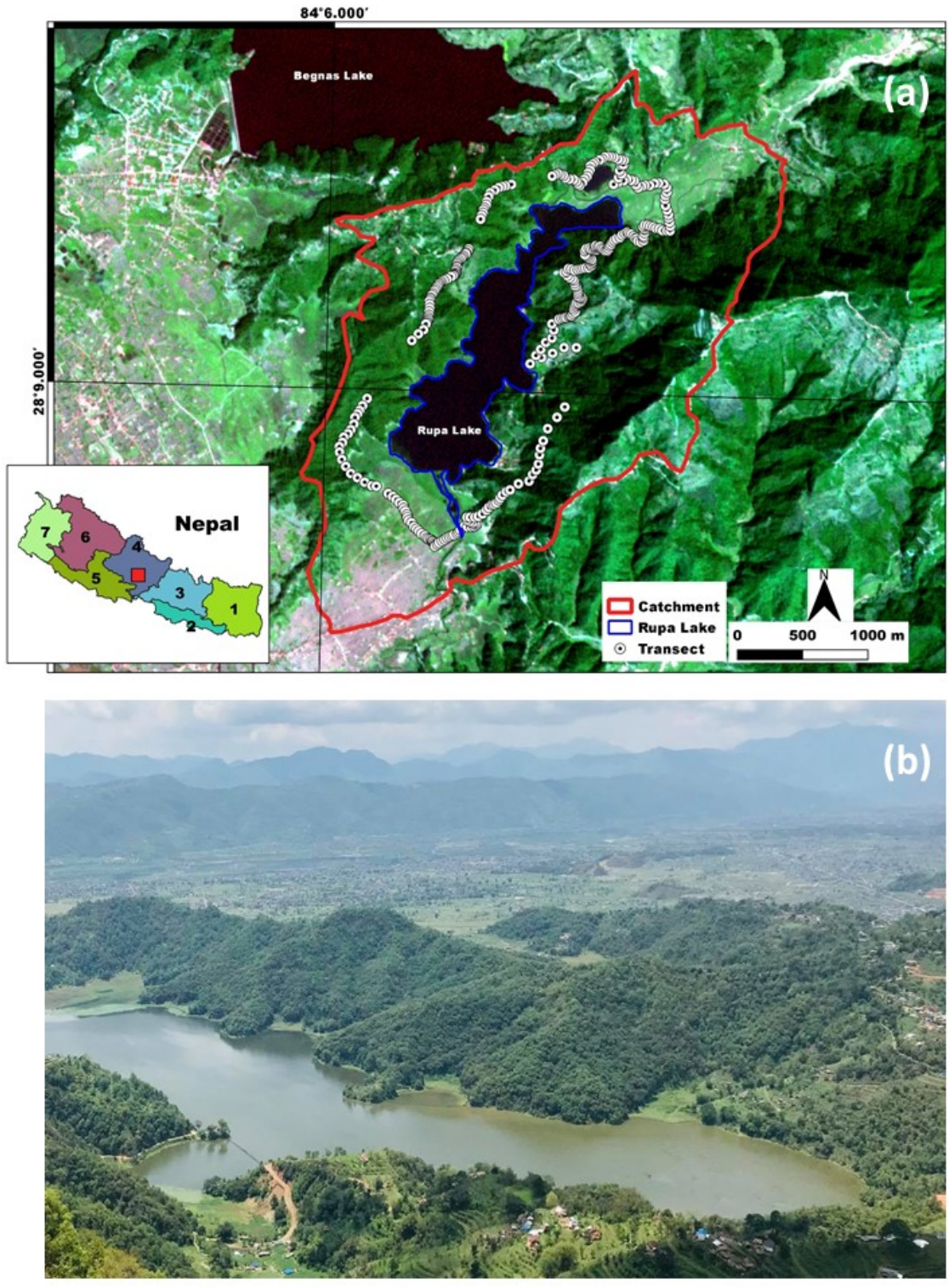

Figure 1 (a) Geographic location of the study area shown on Rapid eye image from March 16, 2019; Rupa 
Lake is outlined in blue, the catchment area is outlined in red, and white markers indicate the locations of study transects. (b) A photograph of Rupa Wetland, showing the land use and land cover types in the study area (@Damodar Bhakta Thapa).

\subsection{Data analysis}

We calculated the Shannon-Weiner diversity index (Shannon and Weaver, 1949), Simpson Index (Simpson, 1949), species richness, Pielou's evenness (Pielou, 1966), Margalef's richness index (Margalef, 1958), and relative abundance of each butterfly family to quantify butterfly diversity in the Rupa wetland. The ShannonWeiner diversity index provides information about the community composition of species; the higher the number, the higher the species diversity. Simpson's index is a weighted arithmetic mean of proportional abundance and measures the probability that two individuals randomly selected from a sample will belong to the same species. It is a dominance index because it gives more weight to common or dominant species, whereas the Shannon-Weiner index gives more weight to rare species. Simpson's index ranges from to 0 to 1 with 0 representing infinite diversity and 1 representing no diversity, so the larger the value of $\mathrm{D}$, the lower the diversity. Species richness denotes the total number of species observed within an area. Margalef's index was used as a simple measure of species richness (Margalef, 1958) and Pielou's evenness index (e) was used for calculating the evenness of species (Pielou, 1966). Species abundance denotes the total number of individuals observed during the study period.

Shannon Index $(H)=-\sum_{\mathbf{i}=\mathbf{1}}^{\mathbf{n}} \mathbf{p}_{\mathrm{i}} \ln \mathrm{p}_{\mathbf{i}} \ldots \ldots \ldots \ldots$. Eq. 1

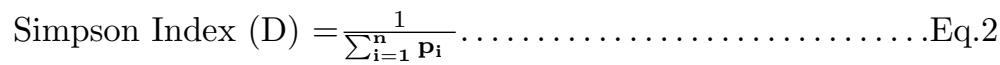

Pielou's evenness index $(\mathrm{e})=\frac{H}{\ln (S)} \ldots \ldots \ldots \ldots \ldots$.Eq. 3

Margalef's richness index $=\frac{S-1}{\ln (N)} \ldots \ldots \ldots \ldots \ldots$.. Eq. 4

Where, $H$ is the Shannon-Weiner species diversity index, D is the Simpson's diversity index, $S$ is the number of species, $p_{i}$ is the proportion of individuals belonging to the $\mathrm{i}^{\text {th }}$ species, and $\mathrm{N}$ is the total number of individuals.

For our butterfly-plant interaction data, we used generalized linear modelling (GLM) (Nelder and Wedderburn, 1972) to identify the factors affecting nectar plant choice by butterflies. Butterfly species abundance was used as the dependent variable whereas flower colour, plant category, and corolla shape were used as independent variables with a Poisson distribution. We used nested likelihood ratio tests (Neyman and Pearson, 1933) to choose the best model, followed by Turkey's post-hoc tests (Tukey, 1949) in the case of significant predictors. Differences were considered significant at $\mathrm{p}<0.05$. Additionally, Pearson's correlation coefficient was used to test for a significant relationship between the proboscis length of butterflies and the corolla depth of flowers.

\section{Results}

\subsection{Butterfly species and their individuals}

All together, 1,535 individuals of 138 species representing all six families of butterflies were counted and recorded in the single wetland. Among them, Punchinello (Zemeros flegyas, 92 individuals) and Grey pansy (Junonia atlites, 80 individuals) butterflies were the most abundant species, followed by Straight swift (Parnara guttata, 69 individuals), Common five ring (Ypthima baldus, 45 individuals), and Common grass yellow (Eurema hecabe, 38 individuals) butterflies. The least common species included Pioneer $(B e-$ lonois aurota, 1 individual), Common batwing (Troides helena, 1 individual), Tree yellow (Gandaca harina, 1 individual), Pale Wanderer (Pareronia avatar, 2 individuals), Yellow orange tip (Ixias pyrene, 2 individuals), Peablue (Lampides boeticus, 3 individuals), Chocolate albatross (Appias lyncida, 4 individuals), 
Dark cerulean (Jamides bochus, 5 individuals), and Dark pierrot (Tarucus ananda, 8 individuals) butterflies (Annex 1).

The family with the most observed individuals was the Nymphalidae family (650 individuals of $62 \mathrm{spp}$ ), followed by Lycaenidae (319 individuals of $29 \mathrm{spp}$ ), Pieridae (181 individuals of $20 \mathrm{spp}$ ), Hespiridae (163 individuals of $10 \mathrm{spp}$ ), Riodinidae (132 individuals of $4 \mathrm{spp}$ ) and Papilionidae (90 individuals of $13 \mathrm{spp}$ ) (Figure 2).

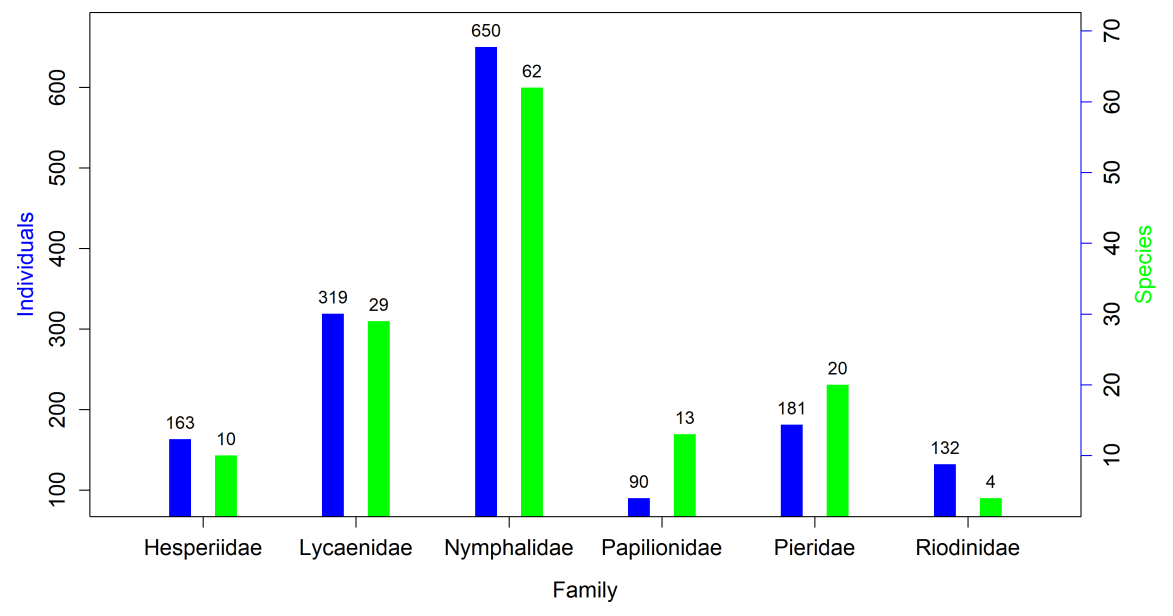

Figure 2. The number of individuals and species of each butterfly family observed in Rupa Wetland, Nepal.

\subsection{Species diversity, evenness and richness}

In our study area, we observed 3 common, 29 not rare, 61 rare, and 45 very rare butterfly species (Annex 1). Family Nymphalidae had the highest Shannon diversity index of 3.50 while family Riodinidae showed the lowest diversity with a value of 0.84 . The overall Shannon diversity index, Simpson's index, species richness, Pielou evenness and Margalef richness index of butterfly fauna in Rupa wetland (pooling all families) were $4.33,0.98,138,0.87$, and 18.67 , respectively. Diversity indices for each family in the Rupa Wetland are summarized in Table 1.

Table 1. The Shannon-Weiner diversity index, Simpson diversity index, species richness, Pielou's evenness, and Margalef's richness index calculated for each butterfly family observed in Rupa Wetland, Nepal, as well as the overall values when data from all families were pooled together.

\begin{tabular}{llllll}
\hline Family & Shannon Index & Simpson Index & $\begin{array}{l}\text { Species } \\
\text { richness }\end{array}$ & $\begin{array}{l}\text { Pielou } \\
\text { evenness }\end{array}$ & $\begin{array}{l}\text { Margalef's } \\
\text { Richness } \\
\text { Index }\end{array}$ \\
Hesperiidae & 1.72 & 0.76 & 10.00 & 0.75 & 1.23 \\
Lycaenidae & 2.99 & 0.94 & 29.00 & 0.89 & 3.82 \\
Nymphalidae & 3.50 & 0.96 & 62.00 & 0.85 & 8.31 \\
Papilionidae & 2.11 & 0.85 & 13.00 & 0.82 & 1.64 \\
Pieridae & 2.48 & 0.89 & 20.00 & 0.83 & 2.59 \\
Riodinidae & 0.84 & 0.46 & 4.00 & 0.60 & 0.41 \\
All families & 4.33 & 0.98 & 138 & 0.87 & 18.67 \\
\hline
\end{tabular}




\subsection{Effects of flower color, plant category and corolla shape on butterfly abun- dance}

Out of the 138 butterfly species observed, only 31 species consisting of 298 individuals were observed feeding at flowers; they were recorded at a total of 28 nectar plant species. When all 31 butterfly species were analyzed together, results of the GLM revealed that butterfly visitation was significantly influenced by plant category $\left(\chi^{2}{ }_{1}=0.50, \mathrm{p}=0.48\right)$, flower colour $\left(\chi^{2}{ }_{4}=12.3, \mathrm{p}=0.015\right)$, and corolla shape $\left(\chi^{2}{ }_{1}=1.22, \mathrm{p}\right.$ $=0.27$ ) (Figure 3). Butterflies significantly preferred the flowers of herbaceous plants over woody plants (Figure 3A), and tubular flowers over non-tubular flowers (Figure 3C). Moreover, Tukey's test revealed that butterfly abundance was significantly greater at yellow, white, and purple flowers than at pink flowers $(\mathrm{p}<$ 0.05; Figure 3B). Examining each butterfly family separately revealed different results (Figure 4). For four of the families (Lycaenidae, Nymphalidae, Papilionidae, and Pieridae), none of the tested factors (flower color, plant category, and corolla shape) were shown to significantly influence butterfly abundance at flowers (Figure 4D-O). However, Hesperidae abundance was found to be significantly influenced by both flower colour $\left(\chi_{3}^{2}=12.1, \mathrm{p}=0.007\right)$, with more butterflies observed at yellow flowers than purple flowers (Figure 4B), and flower shape $\left(\chi_{1}^{2}=5.78, \mathrm{p}=0.02\right)$, with more butterflies observed at tubular flowers than non-tubular flowers (Figure 4C).
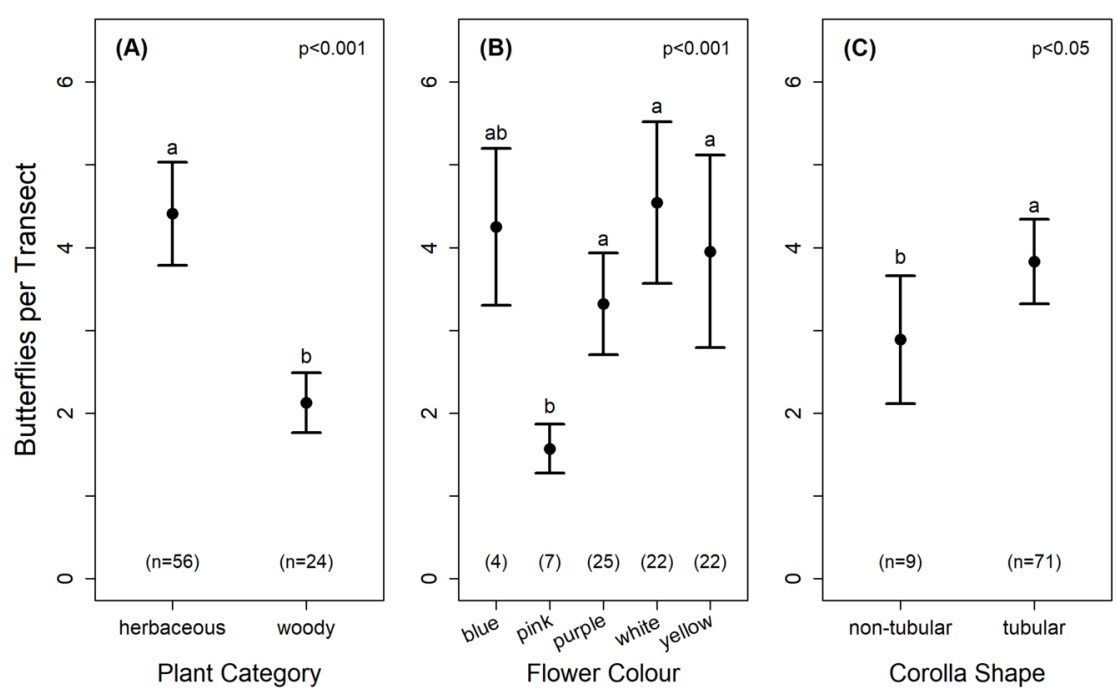

Figure 3. The mean ( \pm SE) number of butterflies observed per transect at $(A)$ the flowers of herbaceous versus woody plant species, (B) different floral colours, and (C) non-tubular versus tubular flowers. Within each graph, different lowercase letters indicate significant differences. Numbers in parentheses at the bottom of each graph indicate the sample sizes (number of sightings). 

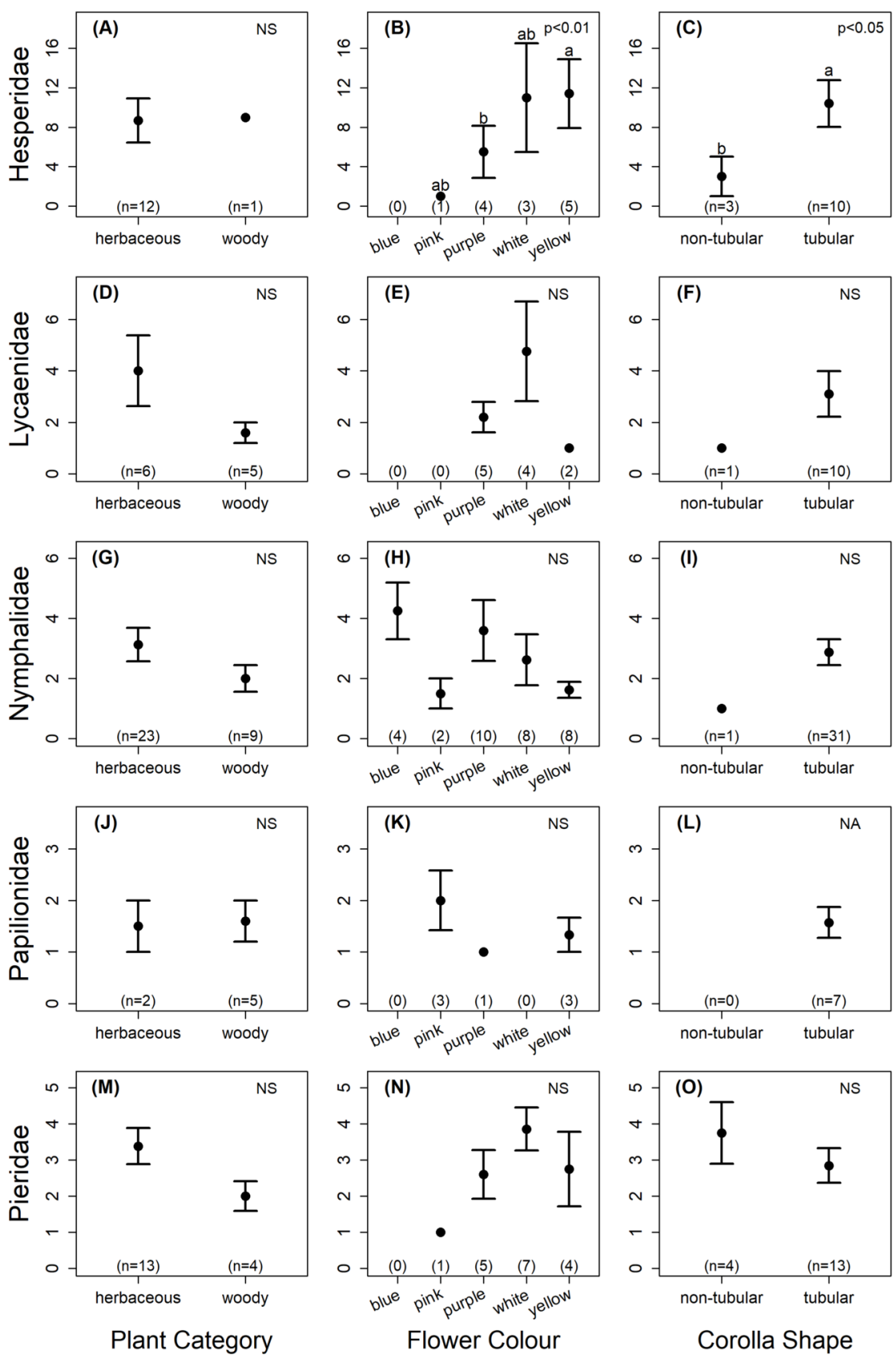

Figure 4. The mean ( \pm SE) number of butterflies observed per transect for each of 5 butterfly families observed: (A-C) Hesperidae, (D-F) Lycaenidae, (G-I) Nymphalidae, (J-L) Papilionidae, and (M-O) Pieridae. Graphs show the number of butterflies at (A, D, G, J, M) the flowers of herbaceous versus woody plant species, $(\mathrm{B}, \mathrm{E}, \mathrm{H}, \mathrm{K}, \mathrm{N})$ different floral colours, and (C, F, I, L, O) non-tubular versus tubular flowers. Within each graph, different lowercase letters indicate significant differences. Numbers in parentheses at the bottom of each graph indicate the sample sizes (number of sightings). 


\subsection{Number of butterfly species feeding at nectar plant species}

To ascertain the popularity of nectar plant species, the total number of butterfly species observed feeding on each plant species was counted. Twenty-eight nectar host plant species were observed receiving butterfly visits. Bidens pilosa was visited by the most butterfly species (13 species), followed by Eupatorium odoratum (11 species),Lantana camara (10 species), and Ageratum houstonianum (6 species); 15 plant species were visited by a single butterfly species (Figure 3A). Parnara guttata butterflies visited the most plant species (10 species), followed by Catopsilia pyranthe (5), Eurema hecabe (5) and Appias lyncida (4), whereas 9 butterfly species visited only a single plant species (Figure 3B).

(A)

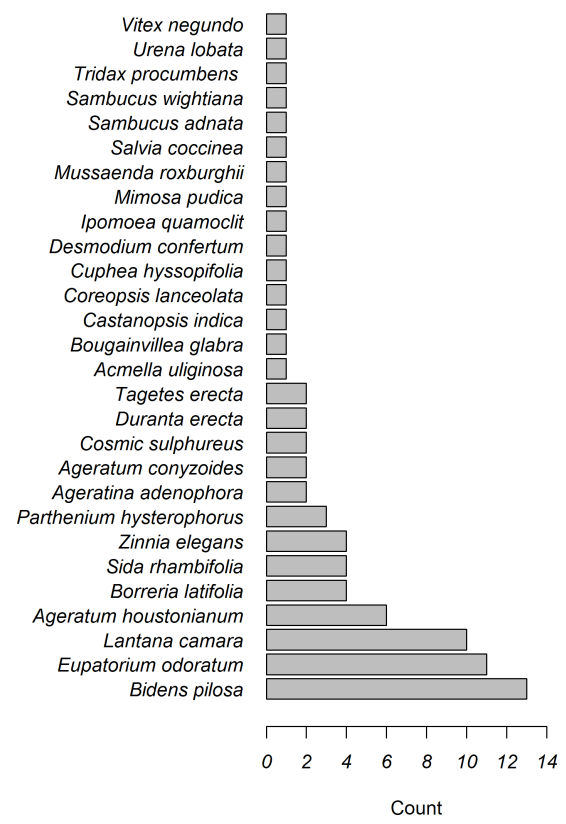

(B)

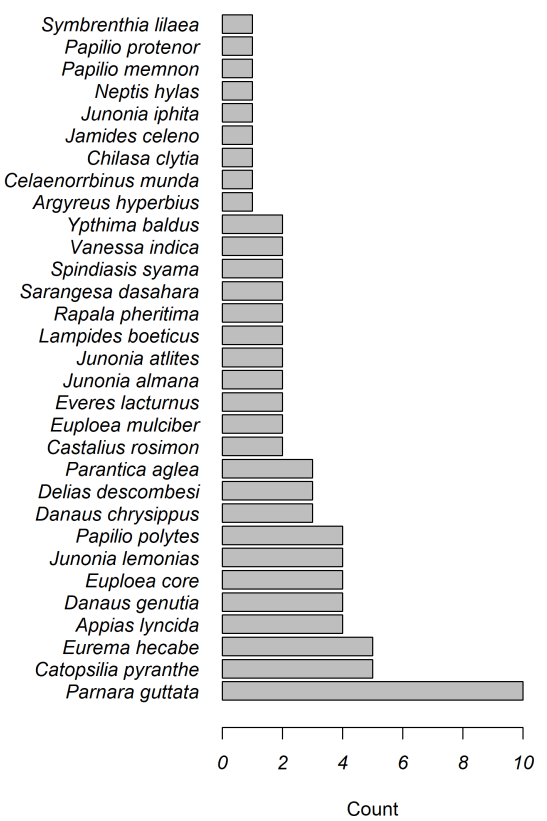

Figure 5. Plant species visited by number of butterflies species (A) and number of plant species visited by each butterfly species (B).

\subsection{Correlation between proboscis length and corolla tube length}

Our results show a significant correlation between the proboscis length of butterflies and the corolla tube length of visited flowers $(\mathrm{p}<0.001, \mathrm{r}=0.466$; Figure 6$)$. The shortest mean proboscis length was $7.10 \mathrm{~mm}$ for Lycaenidae and the longest was $25.71 \mathrm{~mm}$ for Papilionidae (Appendix 3). Similarly, the shortest mean corolla tube length was $4.38 \mathrm{~mm}$ for flowers visited by Hesperidae butterflies and the longest was $19.43 \mathrm{~mm}$ for flowers visited by Papilionidae butterflies. 


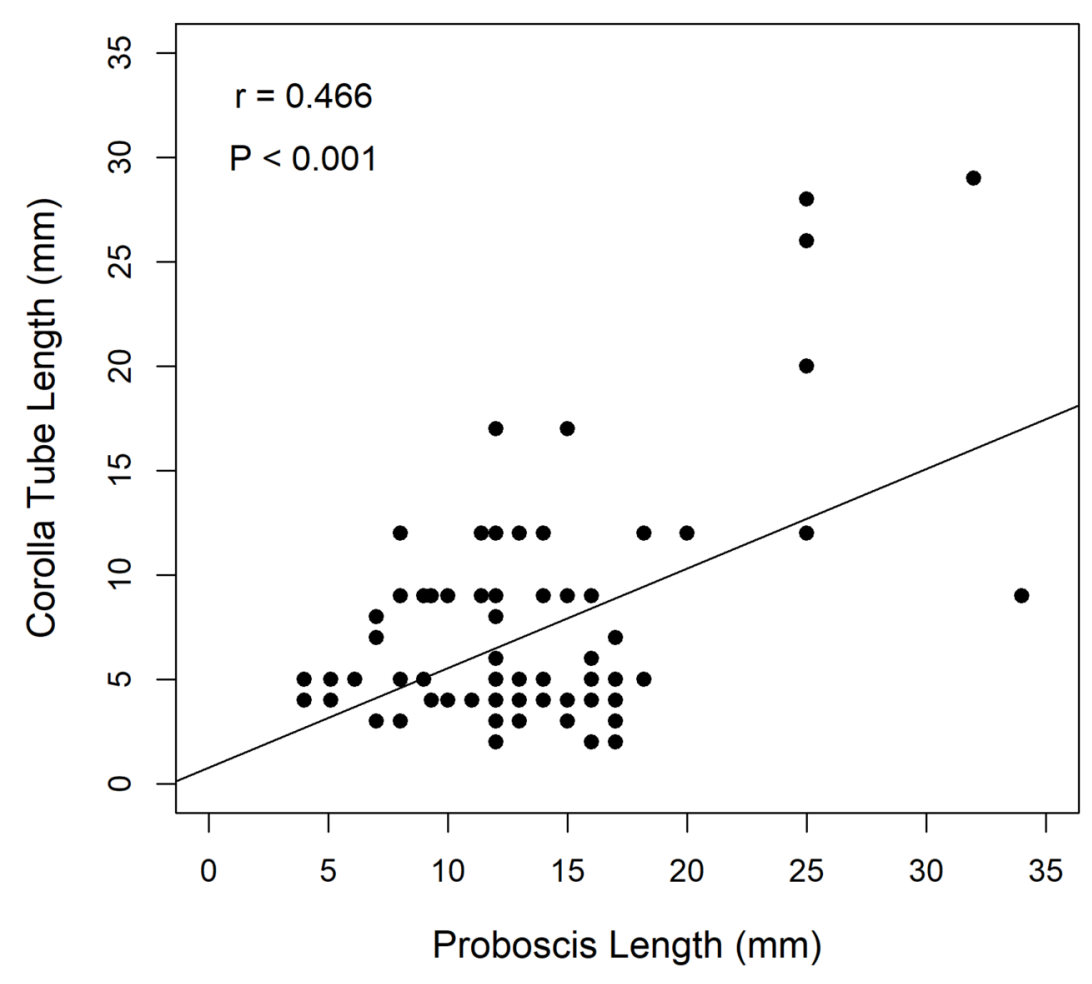

Figure 6. A scatterplot showing the significant positive correlation between butterfly proboscis length and corolla tube length of the flowers they foraged at in Rupa Wetland, Nepal.

\section{Discussion}

A total of 1,535 individuals from 138 species representing all six families of butterflies were counted and recorded in the single wetland. Similarly, Smith et al (2016) recorded a total of 174 butterfly species in Rupa and Begnas Lakes. In our study, the Nymphalidae had the highest diversity followed by the Lycaenidae family. Previous studies have also reported Nymphalidae to have the highest species richness, followed by Lycaenidae and others (Kunte, 1997; Prajapati, Shrestha and Tamrakar, 2000; Shrestha et al ., 2018; Tamang, Joshi and Shrestha, 2019). Moreover, similar findings have also been reported in other wetlands in India, such as at Oussudu Lake (Murugesan, Arun and Prusty, 2013) and the Kole Wetlands (Sarath, Sreekumar and Nameer, 2017). The rich biodiversity of butterfly fauna in Rupa Wetland is likely due to the rich vegetation in this area, which offers abundant floral resources for them to forage on. Interestingly, there was large variation in diversity among families. Some butterfly families observed in Rupa Wetland had quite high diversity (i.e., Nymphalidae), while others had lower diversity (i.e., Riodinidae and Hesperiidae), which may be due to a number of reasons. One possible explanation is that most nymphalids are polyphagous in nature, which makes it easier for them to utilize a variety of habitats (Janz, 2005). A second possible explanation may be that many species in this family are strong active fliers, which likely helps them cover large areas when searching for resources (Eswaran and Pramod, 2005; Padhye et al., 2006). Additionally, the families with relatively low diversity in Rupa Wetland may be limited by a lack of appropriate host plants; a 
study in South Germany found that the butterfly families with lower species richness were limited by a lack of host plants for the growing caterpillars (Steffan-Dewenter and Tscharntke, 1997).

When examining all butterfly species pooled together, all three factors examined (plant category, flower colour, and corolla shape) were found to significantly influence butterfly visitation at nectar plants. Butterflies visited the flowers of herbaceous plant species significantly more often than the flowers of woody species. Similar to our results, a previous study in Japan found that nectar utilization by adult butterflies was substantially higher at herbaceous plants than at woody species, even though the study was conducted in and near a woodland (Kitahara, Yumoto and Kobayashi, 2008). Additionally, a study by Santhosh and Basavarajappa, (2016) found that weeds contributed the most nectar to butterfly species, followed by shrubs, herbs, trees and climbers. Nimbalkar et al., (2011) also reported that visits of butterflies were more frequent to the flowers of herbs and shrubs than to the flowers of trees. This apparently common preference that butterfly species exhibit towards herbaceous plants may be due to the abundance of such host plants. For example, a study conducted by Sengupta and Ghorai (2013) in the hill forests of West Bengal, India found that Pierid and Hesperid butterfly families were mostly dependent on epiphytic flora due to large availability of Ochideaceae plants within their study area. Because herbaceous species appear to offer attractive floral resources to butterflies, maintenance of herbaceous plants in probable habitats may be one method to increase the richness and diversity of butterfly species.

In addition to plant category, flower colour was also found to influence butterfly visitation. In our study, butterflies visited yellow, white, and purple flowers significantly more often than pink flowers. Previous studies examining floral colour preferences in butterflies have reported a wide range of results. For example, one study in India found that butterflies visited red, yellow, blue and purple flowers more often than white and pink flowers (Tiple, Deshmukh and Dennis, 2005). In contrast, a different study in India found that butterflies preferred yellow, white, pink and blue flowers (Santhosh and Basavarajappa, 2016). The overall preference for yellow, white, and purple flowers in our study appears to be driven by Hesperidae, Lycaenidae, and Pieridae, as these families were rarely (0-1 individuals per transect) seen visiting pink or blue flowers (Figure 4). In contrast, Nymphalidae butterflies visited blue flowers more often than the other colors, and Papilionidae visited pink flowers most often, although the differences were not significant. Similar to our results, a previous study found that a Nymphalid butterfly species showed a color preference for both blue and yellow flowers (Ômura and Honda, 2005), and a different study reported that a Papilionidae species preferred red and purple flowers (Kandori and Yamaki, 2012). The diverse findings reported in previous studies is unsurprising given that there is high variation in floral rewards, both within and across plant species (Yan et al ., 2016). Moreover, butterflies are known to be quick learners, and will readily choose high-rewarding colors over innate color preferences (Blackiston et al., 2011; Kandori and Yamaki, 2012). Thus, further research is necessary to determine the innate and acquired color preferences of Nepalese butterflies.

The third trait examined, corolla shape, revealed that butterflies visited tubular flowers significantly more often than non-tubular flowers. Our results are similar to those of Tiple and colleagues (2005), who also found that butterflies in India visited tubular flowers more often than non-tubular flowers. Moreover, the findings of Nimbalkar et al., (2011) also showed that most butterflies prefered tubular flowers over non-tubular ones. Raju et al., (2004) reported butterflies feeding on both tubular and non tubular flowers, but exhibited a preference for tubular flowers. This generally universal preference that butterflies have for tubular flowers is unsurprising, given the suitable morphological fit between butterfly proboscises and tubular corolla tubes (Sultana et al ., 2017).

Not only did we find that butterflies preferred tubular flowers, but we also observed a significant correlation between the proboscis length of butterflies and the corolla tube length of visited flowers. This finding indicates that butterfly with short proboscises prefer flowers with short corolla tube lengths and vice versa. At the same time, this finding supports the use of proboscis length as a morphological indicator of resource utilization in butterflies. Similar findings were recorded in the study by (Corbet, 2000) which showed that the maximum corolla depth of potential nectar plants limits the species feeding on them to those with sufficiently long 
proboscises; short-tongued butterfly species are therefore unable to feed on deep flowers. Moreover, (Sultana et al. , 2017) found that the proboscis had significant role in the co-evolution between butterflies and their nectaring plants. They reported that flowers are only fed upon when they remain within the range of the proboscis length. Szigeti et al (2020) investigated the relation between flower visits and the proboscis length of Clouded Apollo butterflies and found that the longer the proboscis, the more likely such butterflies were to forage on plants with the deepest corollas. Our study shows that Lycaenidae and Pieridae butterflies prefer flowers with relatively shallow corollas, Nymphalidae and Hesperidae with moderately deep corollas, and Papilionidae butterflies with the deepest corollas. A previous study by (Tiple, Khurad and Dennis, 2009) in central India also showed that Papilionids foraged on flowers with long corolla tubes. Similarly, (Ranta and Lundberg, 1980) reported that species with the longest proboscises were able to utilize the highest range of corolla tube depths. Thus, a long proboscis permits feeding on a greater variety of flowering plant species.

When analyzing butterfly visitation by family, Hesperidae were found to prefer yellow flowers over purple, and tubular flowers over non-tubular, but for the remaining four families examined (Lycaenidae, Nymphalidae, Papilionidae, and Pieridae), none of the tested factors (plant category, flower colour, and corolla shape) were shown to significantly influence butterfly abundance at flowers. This lack of significant findings may be due to small sample sizes, as we only observed 32 Lycaenidae, 90 Nymphalidae, 11 Papilionidae, and 52 Pieridae individuals foraging, in contrast to the 113 Hesperidae individuals observed foraging. Additionally, it is possible that individual species within each family have different preferences, resulting in the apparent lack of preferences at the family level. Moreover, butterfly foraging preferences appear to be flexible, as a previous study has suggested that although butterfly species may seem to exhibit specific preferences, their choices ultimately depend on the relative abundance of preferred traits (Arroyo et al. , 2007). Thus, more detailed studies (particularly at the species level) are necessary to fully understand butterfly foraging preferences. Such information is necessary to promote the diversity of butterfly species, which will ultimately help balance the diverse ecosystems that these important pollinators occupy.

\section{Conclusions}

This study examined the different factors affecting the choice of nectar plants of some Himalayan butterflies. Our findings show that plant category, flower colour, corolla shape, and corolla tube length all influenced butterfly foraging. The study suggests that Rupa Lake is a resource enriched habitat for different butterfly species. The wild patches within the wetlands are flourishing foraging grounds for butterflies, but are sub-

jected to human disturbances. The management of such habitats is urgently required for the conservation of butterfly diversity. Before our study, Rupa was considered important in terms of PES (payment for ecosystem services), tourism, and recreation, but never realized in terms of harboring such diverse pollinators, which not only play an important role in the wetland area, but also in the surrounding agriculture farmlands too. Thus, our study further emphasizes the need to protect such wetlands for multiple purposes. This study not only confirms the importance of providing nectar resources for butterflies, but also reveals which types of resources are most appropriate for butterfly fauna. Cultivating native plant species preferred by butterflies will provide a more suitable habitat for these important pollinators. Finally, the high butterfly diversity found in the shrubland surrounding Rupa Lake reveals that conservation of such areas is necessary, and we recommend that such areas be declared as butterfly parks or butterfly zones to promote public awareness and conservation efforts.

\section{Acknowledgements}

We would like to acknowledge Mr. Peter Smetacek, Mr. Anoj Subedi, Ms. Shristee Panthee, Mr. Basanta Sharma, Mr. Sanjaya Tamang, Mr. Bhaiya Khanal, Mr. Jay Raj Joshi, Mr. Amrit Poudel, and Mr. Mahendra Singh Limbhu for their support during fieldwork and data analysis. The Department of Forests, Babarmahal Kathmandu, granted the research permit for conducting research in Rupa Wetland. We also 
acknowledge Planet.org for the Rapid Eye image used in this paper. Hari Adhikari acknowledges funding from the Academy of Finland for the SMARTLAND project (decision number 318645).

\section{DATA AVAILABILITY STATEMENT}

Data are available on Dryad.URL:

https://datadryad.org/stash/share/sl1Gxc2KGVXJVqFWj40UmuBRAUAnWYo0JEffP0meEw4

https://doi.org/10.5061/dryad.qnk98sfdg

\section{References}

Ackerman, J. D. (2000) 'Abiotic pollen and pollination: ecological, functional, and evolutionary perspectives', in Pollen and Pollination. Springer, pp. 167-185.

Arroyo, M. T. K. et al. (2007) 'Display size preferences and foraging habits of high Andean butterflies pollinating Chaetanthera lycopodioides (Asteraceae) in the subnival of the central Chilean Andes', Arctic, Antarctic, and Alpine Research . Taylor \& Francis, 39(3), pp. 347-352.

Bernays, E. and Graham, M. (1988) 'On the evolution of host specificity in phytophagous arthropods', Ecology . Wiley Online Library, 69(4), pp. 886-892.

Bhusal, D. R. and Khanal, B. (2008) 'Seasonal and altitudinal diversity of butterflies in eastern Siwalik of Nepal', Journal of Natural History Museum , 23, pp. 82-87.

Blackiston, D., Briscoe, A. D. and Weiss, M. R. (2011) 'Color vision and learning in the monarch butterfly, Danaus plexippus (Nymphalidae)', Journal of Experimental Biology. The Company of Biologists Ltd, 214(3), pp. 509-520.

Boggs, C. L. and Ross, C. L. (1993) 'The effect of adult food limitation on life history traits in Speyeria mormonia (Lepidoptera: Nymphalidae)',Ecology . Wiley Online Library, 74(2), pp. 433-441.

Caldas, A. and Robbins, R. K. (2003) 'Modified Pollard transects for assessing tropical butterfly abundance and diversity', Biological Conservation. Elsevier, 110(2), pp. 211-219.

Corbet, S. A. (2000) 'Butterfly nectaring flowers: butterfly morphology and flower form', Entomologia Experimentalis et Applicata. Wiley Online Library, 96(3), pp. 289-298.

Cruden, R. W. and Hermann-Parker, S. M. (1979) 'Butterfly pollination of Caesalpinia pulcherrima, with observations on a psychophilous syndrome', The Journal of Ecology . JSTOR, pp. 155-168.

Dangol, D. R. (2015) 'Contributions of Botanists of Natural History Museum (Tribhuvan University) to Research and Education in Nepal', Journal of Natural History Museum , 29, pp. 122-147.

Durairaj, P. and Sinha, B. (no date) 'Review of butterflies (Lepidoptera: Rhopalocera) from Arunachal Pradesh: Conservation status and importance of research in protected areas', Zoology for future education and research, pp. 61-77.

Ehrlich, P. R. and Raven, P. H. (1964) 'Butterflies and plants: a study in coevolution', Evolution . JSTOR, pp. 586-608.

Erhardt, A. (1991) 'Flower preferences, nectar preferences and pollination effects of Lepidoptera', Adv. Ecol , 1, pp. 239-260.

Eswaran, R. and Pramod, P. (2005) 'Structure of butterfly community of Anaikatty hills, Western Ghats', Zoos' Print Journal , 20(8), pp. 1939-1942.

Fernando, E. et al. (2019) 'Atrophaneura varuna'. The IUCN Red List of Threatened Species.

Freitas, L. and Sazima, M. (2003) 'Floral biology and pollination mechanisms in two Viola species-from nectar to pollen flowers?', Annals of Botany . Oxford University Press, 91(3), pp. 311-317. 
Gautam, D. et al. (2019) 'Climatic Variability and Wetland Resources in Rupa Lake Catchment, Nepal'.

GoN, W. (2011) 'Water Resources of Nepal in the Context of Climate Change'. Kathmandu.

Hoyle, M. and James, M. (2005) 'Global warming, human population pressure, and viability of the world's smallest butterfly', Conservation Biology . Wiley Online Library, 19(4), pp. 1113-1124.

ICIMOD [International Center for Integrated Mountain Development] (2007) 'Nepal Biodiversity Resource Book (Protected Areas, Ramsar Sites, and World Heritage Sites)', Sites The Journal Of 20Th Century Contemporary French Studies, pp. 1-161.

Ilse, D. (1928) 'Uber den farbensinn der Tagfalter', Zeitschrift fur vergleichende Physiologie . Springer, 8(3-4), pp. 658-692.

Janz, N. (2005) 'The relationship between habitat selection and preference for adult and larval food resources in the polyphagous butterfly Vanessa cardui (Lepidoptera: Nymphalidae)', Journal of Insect Behavior . Springer, 18(6), pp. 767-780.

Kafle, G. et al. (2008) 'Status of and threats to waterbirds of Rupa Lake, Pokhara, Nepal', Journal of Wetlands Ecology, pp. 9-12.

Kandori, I. and Yamaki, T. (2012) 'Reward and non-reward learning of flower colours in the butterfly Byasa alcinous (Lepidoptera: Papilionidae)', Naturwissenschaften . Springer, 99(9), pp. 705-713.

Khanal, B. (2006) 'The Late Season Butterflies of Koshi Tappu Wildlife Reserve, Eastern Nepal', Our Nature , 4(1), pp. $42-47$.

Khanal, B., Chalise, M. K. and Solanki, G. S. (2013) 'Population status and threats of Phaedyma aspasia kathmandia Fujioka 1970 (Lepidoptera: Nymphalidae), an endemic subspecies of butterfly in Godavari Forest of Central Nepal', Journal of Natural History Museum, 27, pp. 87-91.

Khanal, B., Shrestha, K. and Shrestha, M. K. (2014) 'Status Monitoring and Conservation Issues of Teinopalpus Imperialis Hope (Lepidoptera: Papilionidae), an Endangered Butterfly of Nepal', Journal of Natural History Museum, 28, pp. 49-56.

Kitahara, M., Yumoto, M. and Kobayashi, T. (2008) 'Relationship of butterfly diversity with nectar plant species richness in and around the Aokigahara primary woodland of Mount Fuji, central Japan',Biodiversity and Conservation. Springer, 17(11), pp. 2713-2734.

Kunte, K. J. (1997) 'Seasonal patterns in butterfly abundance and species diversity in four tropical habitats in northern Western Ghats', Journal of Biosciences . Springer, 22(5), pp. 593-603.

Larsson, M. (2005) 'Higher pollinator effectiveness by specialist than generalist flower-visitors of unspecialized Knautia arvensis (Dipsacaceae)', Oecologia . Springer, 146(3), pp. 394-403.

Margalef, R. (1958) 'Temporal succession and spatial heterogeneity in phytoplankton', Perspectives in marine biology . University of California press, pp. 323-349.

McDermott Long, O. et al. (2017) 'Sensitivity of UK butterflies to local climatic extremes: which life stages are most at risk?',Journal of Animal Ecology . Wiley Online Library, 86(1), pp. 108-116.

MFSC (2014) 'Nepal National Biodiversity Strategy and Action Plan 2014-2020', Ministry of Forest and Soil Conservation (MFSC), Kathmandu, Nepal .

MoFE (2018) 25 Years of Achievements on Biodiversity Conservation in Nepal, Environment and Biodiversity Division, Ministry of Forests and Environment (MoFE) .

Muhammad, A. et al. (2018) 'Extension of known distribution of Moore's Five Ring Butterfly Ypthima nikaea to Pakistan, Nepal and Meghalaya, India (Lepidoptera: Nymphalidae: Satyrinae)',Bionotes , 20(2), pp. $55-56$. 
Murugesan, M., Arun, P. R. and Prusty, B. A. K. (2013) 'The butterfly community of an urban wetland system-a case study of Oussudu Bird Sanctuary, Puducherry, India', Journal of Threatened Taxa, 5(12), pp. $4672-4678$.

Nelder, J. A. and Wedderburn, R. W. M. (1972) 'Generalized linear models', Journal of the Royal Statistical Society: Series A (General). Wiley Online Library, 135(3), pp. 370-384.

Nepali, K. B., Lamichhane, D. and Shah, S. (2018) 'Diversity of Butterfly and its Relationship with Plants in National Botanical Garden, Godawari, Lalitpur, Nepal', JOURNAL OF PLANT RESOURCES , 16(1), p. 124.

New, T. R. et al. (1995) 'Butterfly conservation management', Annual review of entomology . Annual Reviews 4139 El Camino Way, PO Box 10139, Palo Alto, CA 94303-0139, USA, 40(1), pp. 57-83.

New, T. R. (2011) 'Launching and steering flagship Lepidoptera for conservation benefit', Journal of Threatened Taxa, pp. 1805-1817.

Neyman, J. and Pearson, E. S. (1933) 'IX. On the problem of the most efficient tests of statistical hypotheses', Philosophical Transactions of the Royal Society of London. Series A, Containing Papers of a Mathematical or Physical Character. The Royal Society London, 231(694-706), pp. 289-337.

Nimbalkar, R. K., Chandekar, S. K. and Khunte, S. P. (2011) 'Butterfly diversity in relation to nectar food plants from Bhor Tahsil, Pune District, Maharashtra, India', Journal of Threatened Taxa, 3(3), pp. 1601-1609.

Omura, H. and Honda, K. (2005) 'Priority of color over scent during flower visitation by adult Vanessa indica butterflies', Oecologia . Springer, 142(4), pp. 588-596.

Padhye, A. D. et al. (2006) 'Season and landscape wise distribution of butterflies in Tamhini, northern Western Ghats, India',Zoos' Print Journal , 21(3), pp. 2175-2181.

Panthee, S., Limbu, M. S. and Subedi, B. (2019) 'Record of Mycalesis Adamsoni (Watson, 1897)(Lepidoptera: Nymphalidae) from Pokhara and Godavari, Nepal'.

Paudel, N., Adhikari, S. and Paudel, G. (2017) 'Ramsar lakes in the foothills of Himalaya, Pokhara-Lekhnath, Nepal: An overview',Janapriya Journal of Interdisciplinary Studies , 6, pp. 134-147.

Paudel, P. K., Bhattarai, B. P. and Kindlmann, P. (2012) 'An overview of the biodiversity in Nepal', in Himalayan biodiversity in the changing world. Springer, pp. 1-40.

Pielou, E. C. (1966) 'The measurement of diversity in different types of biological collections', Journal of theoretical biology. Elsevier, 13, pp. 131-144.

Poel, P. Van Der et al. (2020) 'Four new butterfly species for Nepal: Abisara chela, Tagiades japetus, Lethe dura and Lethe distans.', Bionotes, 22(1), pp. 21-23.

Pohl, N. B., Van Wyk, J. and Campbell, D. R. (2011) 'Butterflies show flower colour preferences but not constancy in foraging at four plant species', Ecological Entomology , 36(3), pp. 290-300. doi: 10.1111/j.13652311.2011.01271.x.

Pollard, E. (1977) 'A method for assessing changes in the abundance of butterflies', Biological conservation . Elsevier, 12(2), pp. 115-134.

Porter, K. (1992) 'Butterflies and communities', The ecology of butterflies in Britain . Oxford University Press, 7, pp. 139-177.

Prajapati, B., Shrestha, U. and Tamrakar, A. S. (2000) 'Diversity of butterfly in Daman area of Makawanpur district, central Nepal',Nepal Journal of Science and Technology , 2(1). 
Rai, D. (2017) 'Butterfly Diversity In Ghandruk Area Of Mid-Mountain, Nepal'. Central Department of Zoology Institute of Science and Technology Tribhuvan ....

Rajbhandari, B. P. and Shrestha, S. (2014) 'Climate change, food production and food security in Rupa lake wetland area', Nepalese Journal of Agricultural Sciences, p. 26.

Raju, A. J. S., Bhattacharya, A. and Rao, S. P. (2004) 'Nectar host plants of some butterfly species at Visakhapatnam', Science and Culture. SANTIMAY CHATTERJEE, 70(5/6), pp. 187-190.

Ranta, E. and Lundberg, H. (1980) 'Resource partitioning in bumblebees: the significance of differences in proboscis length', Oikos. JSTOR, pp. 298-302.

Sajan, K. C. and Pariyar, S. (no date) 'New Evidence of Himalayan Small-banded Flat Celaenorrhinus nigricans nigricans (de Niceville, 1885) from Nepal'.

Sanchez-Bayo, F. and Wyckhuys, K. A. G. (2019) 'Worldwide decline of the entomofauna: A review of its drivers', Biological conservation. Elsevier, 232, pp. 8-27.

Santhosh, S. and Basavarajappa, S. (no date) 'Study on nectar plants of few butterfly species at agriculture ecosystems of Chamarajanagar District, Karnataka, India'.

Sapkota, A., Kc, S. and Pariyar, S. (2020) 'First record of Pantoporia sandaka davidsoni Eliot , 1969 - Extra Lascar from Nepal', 7(2), pp. 24-26.

Sarath, S., Sreekumar, E. R. and Nameer, P. O. (2017) 'Butterflies of the Kole Wetlands, a Ramsar Site in Kerala, India', Journal of Threatened Taxa, 9(5), pp. 10208-10215.

Sengupta, P. and Ghorai, N. (2013) 'On the plant-butterfly interaction in the surroundings of the upper Neora Valley National Park, a sub-tropical broad leaved hill forest in the eastern Himalayan landscape of West Bengal, India', NEBIO , 4(4), pp. 21-30.

Shannon, C. E. and Weaver, W. (1949) The Mathematical Theory of Communication, by CE Shannon (and Recent Contributions to the Mathematical Theory of Communication), W. Weaver. University of illinois Press.

Shrestha, B. R. et al. (2018) 'Diversity and status of butterflies at different sacred forests of Kathmandu valley, Nepal', Journal of Entomology and Zoology Studies , 6(3), pp. 1348-1356.

Shrestha, B. R. et al. (2020) 'Butterfly-plant interactions and body size patterns along an elevational gradient in the Manang region of central Nepal', Journal of Mountain Science. Springer, pp. 1-13.

Simpson, E. H. (1949) 'Measurement of diversity', nature . Nature Publishing Group, 163(4148), p. 688.

Smith, collin P., Sherpa, L. and Shristi, N. (2016) Butterflies of Begnas and Rupa Watershed, Pokhara, Nepla . LIBIRD.

Smith, C. P. and Majupuria, T. C. (2006) Illustrated checklist of Nepal's butterflies . Walden Book House.

Springett, B. P. (1978) 'On the ecological role of insects in Australian eucalypt forests', Australian Journal of Ecology . Wiley Online Library, 3(2), pp. 129-139.

Stefanescu, C. et al. (2011) 'Recent trends in butterfly populations from north-east Spain and Andorra in the light of habitat and climate change', Journal of Insect Conservation. Springer, 15(1-2), pp. 83-93.

Steffan-Dewenter, I. and Tscharntke, T. (1997) 'Early succession of butterfly and plant communities on set-aside fields', Oecologia . Springer, 109(2), pp. 294-302.

Storrs, A. and Storrs, J. (1990) Trees and Shrubs of Nepal and the Himalayas . Pilgrims Books House.

Sultana, S. et al. (2017) 'Butterfly probosces and their functional relations with the nectar plants in some selected forests', Journal of Biodiversity Conservation and Bioresource Management, 3(1), pp. 93-102. 
Suwal, S. P. et al. (2019) 'Additional distribution records of the rare Nepal Comma Polygonia c-album agnicula (Moore, 1872) (Insecta: Lepidoptera: Nymphalidae) from Rara National Park, Nepal', Journal of Threatened Taxa , 11(14), pp. 14902-14905. doi: 10.11609/jott.4899.11.14.14902-14905.

Szigeti, V. et al. (2020) 'Are all butterflies equal? Population-wise proboscis length variation predicts flower choice in a butterfly', Animal Behaviour. Elsevier, 163, pp. 135-143.

Tamang, S. R. et al. (2019) 'Confirmation of Pale Green Awlet Burara Gomata ( Lepidoptera : Hesperidae ) from Eastern Nepal', (December).

Tamang, S. R., Joshi, A. and Shrestha, B. R. (2019) 'Diversity of butterflies in eastern lowlands of Nepal .', (April).

Tiple, A. D., Deshmukh, V. P. and Dennis, R. L. H. (2005) 'Factors influencing nectar plant resource visits by butterflies on a university campus: implications for conservation', Nota lepidopterologica . SOCIETAS EUROPAEA LEPIDOPTEROLOGICA, 28(3/4), p. 213.

Tiple, A. D., Khurad, A. M. and Dennis, R. L. H. (2009) 'Adult butterfly feeding-nectar flower associations: constraints of taxonomic affiliation, butterfly, and nectar flower morphology', Journal of Natural History . Taylor \& Francis, 43(13-14), pp. 855-884.

Tukey, J. W. (1949) 'Comparing individual means in the analysis of variance', Biometrics . JSTOR, pp. 99-114.

Wagner, D. L., Nelson, M. W. and Schweitzer, D. F. (2003) 'Shrubland Lepidoptera of southern New England and southeastern New York: ecology, conservation, and management', Forest Ecology and Management . Elsevier, 185(1-2), pp. 95-112.

Yan, J. et al. (2016) 'Pollinator responses to floral colour change, nectar and scent promote reproductive fitness in Quisqualis indica (Combretaceae)', Scientific reports . Nature Publishing Group, 6(1), pp. 1-10.

\section{Appendix}

Annex 1: Diversity of Butterfly in Rupa Wetland, Nepal. Based on number of sightings butterfly species were categorized into very rare ( $<2$ sightings), rare (2-15 sightings), not rare ( $15-50$ sightings), and common (50-100 sightings). Single individual of Common batwing (Troides helena ) was recorded in the study area which was categorized as Least Concern species according to IUCN Red List Data.

\begin{tabular}{lllll}
\hline Scientific Name & Local Name & Individuals & Family & Butterfly Status \\
\hline Lethe confuse & Banded tree brown & 10 & Nymphalidae & Rare \\
Ypthima baldus & Common five ring & 45 & Nymphalidae & Not rare \\
Ypthima nikaea & Moore's five ring & 5 & Nymphalidae & Rare \\
Ypthima huebneri & Common four ring & 30 & Nymphalidae & Not rare \\
Ypthima newara & Newari three ring & 6 & Nymphalidae & Rare \\
Ypthilma confuse & Confusing three ring & 2 & Nymphalidae & Very rare \\
Junonia almana & peacock pansy & 12 & Nymphalidae & Rare \\
Junonia lemonias & Lemon pansy & 35 & Nymphalidae & Not rare \\
Junonia orithyra & Blue pansy & 2 & Nymphalidae & Very rare \\
Junonia atlites & Grey pansy & 80 & Nymphalidae Common \\
Junonia iphita & Chocolate pansy & 27 & Nymphalidae & Not rare \\
Tirmala septentrionis & Dark blue tiger & 1 & Nymphalidae & Very rare \\
Parantica tytia & Chestnut tiger & 1 & Nymphalidae & Very rare \\
Danaus genutia & Common tiger & 5 & Nymphalidae & Rare \\
Danaus chrysippus & Plain tiger & 7 & Nymphalidae & Rare \\
Parantica aglea & Glassy tiger & 15 & Nymphalidae & Rare \\
Euploea mulciber & Striped blue crow & 3 & Nymphalidae & Rare
\end{tabular}




\begin{tabular}{|c|c|c|c|c|}
\hline Scientific Name & Local Name & Individuals & Family & Butterfly Status \\
\hline Euploea core & Common Indian Crow & 6 & Nymphalidae & Rare \\
\hline Hestina nama & Circe & 2 & Nymphalidae & Very rare \\
\hline Elymnias hypermnestra & Common palmfly & 1 & Nymphalidae & Very rare \\
\hline Elymnias malelas & Spotted palmfly & 2 & Nymphalidae & Very rare \\
\hline Tanaecia lepidea & Grey count & 29 & Nymphalidae & Not rare \\
\hline Tanaecia julii & Common earl & 43 & Nymphalidae & Not rare \\
\hline Orsotrioena medus & Jungle brown & 33 & Nymphalidae & Not rare \\
\hline Mycalesis francisca & Lilacine bush brown & 7 & Nymphalidae & Rare \\
\hline Mycalesis malsara & White line bush brown & 10 & Nymphalidae & Rare \\
\hline Mycalesis mineus & Dark brand bushbrown & 5 & Nymphalidae & Rare \\
\hline Mycalesis perseus & Common bush brown & 18 & Nymphalidae & Not rare \\
\hline Melanitis leda & Common evening brown & 20 & Nymphalidae & Not rare \\
\hline Melanitis phedima & Dark evening brown & 16 & Nymphalidae & Not rare \\
\hline Lethe insana & Common forester & 1 & Nymphalidae & Very rare \\
\hline Nemetis mekara & Straight red forester & 1 & Nymphalidae & Very rare \\
\hline Argyreus hyperbius & Indian fritillary & 6 & Nymphalidae & Rare \\
\hline Symbrenthia niphanda & Blue tailed jester & 1 & Nymphalidae & Very rare \\
\hline Symbrenthia hypselis & Spotted jester & 1 & Nymphalidae & Very rare \\
\hline Symbrenthia lilaea & Common jester & 10 & Nymphalidae & Rare \\
\hline Pantoporia hordonia & Common Lascar & 8 & Nymphalidae & Rare \\
\hline Euthalia aconthea & Common baron & 11 & Nymphalidae & Rare \\
\hline Neptis hylas & Common sailor & 29 & Nymphalidae & Not rare \\
\hline Neptis cartica & Plain sailor & 7 & Nymphalidae & Rare \\
\hline Neptis sankara & Broad banded sailor & 2 & Nymphalidae & Very rare \\
\hline Neptis zaida bhutanica & Pale green sailor & 1 & Nymphalidae & Very rare \\
\hline Kallima inachus & Orange oakleaf & 4 & Nymphalidae & Rare \\
\hline Doleschallia bisaltide & Autumn leaf & 1 & Nymphalidae & Very rare \\
\hline Cyrestis thyodamas & Common map & 5 & Nymphalidae & Rare \\
\hline Chersonesia risa & Common maplet & 9 & Nymphalidae & Rare \\
\hline Cupha erymanthis & Rustic & 1 & Nymphalidae & Very rare \\
\hline Phalanta phalantha & Common leopard & 15 & Nymphalidae & Rare \\
\hline Polyura athamas & Common nawab & 2 & Nymphalidae & Very rare \\
\hline Aglais cashmirensis & Indian tortoiseshell & 2 & Nymphalidae & Very rare \\
\hline Limenitis danava & Common commodore & 3 & Nymphalidae & Rare \\
\hline Ariadne merione & Common castor & 15 & Nymphalidae & Rare \\
\hline Hypolimnas bolina & Great eggfly & 4 & Nymphalidae & Rare \\
\hline Vanessa indica & Indian red admiral & 6 & Nymphalidae & Rare \\
\hline Vanessa cardui & Painted lady & 2 & Nymphalidae & Very rare \\
\hline Athyma nefte & Colour sergeant & 1 & Nymphalidae & Very rare \\
\hline Athyma selenophora & Staff sergeant & 1 & Nymphalidae & Very rare \\
\hline Athyma ranga & Blackvein sergeant & 2 & Nymphalidae & Very rare \\
\hline Athyma perius & Common sergeant & 12 & Nymphalidae & Rare \\
\hline Abrota ganga & Sergeant major & 1 & Nymphalidae & Very rare \\
\hline Cethosia biblis & Leopard lacewing & 3 & Nymphalidae & Rare \\
\hline Vagrans egista & Vagrant & 5 & Nymphalidae & Rare \\
\hline Papilio polytes & Common Mormon & 22 & Papilionidae & Not rare \\
\hline Papilio helenus & Red Helen & 19 & Papilionidae & Not rare \\
\hline Atrophaneura aidoneus & Common batwing & 1 & Papilionidae & Very rare \\
\hline Papilio protenor & Spangle & 8 & Papilionidae & Rare \\
\hline Papilio bianor & Common Peacock & 3 & Papilionidae & Rare \\
\hline
\end{tabular}




\begin{tabular}{|c|c|c|c|c|}
\hline Scientific Name & Local Name & Individuals & Family & Butterfly Status \\
\hline Papilio paris & Paris Peacock & 8 & Papilionidae & Rare \\
\hline Graphium sarpedon & Common Bluebottle & 3 & Papilionidae & Rare \\
\hline Papilio memnon & Great Mormon & 12 & Papilionidae & Rare \\
\hline Troides helena & Common birdwing & 1 & Papilionidae & Very rare \\
\hline Pachliopta aristolochiae & Common Rose & 1 & Papilionidae & Very rare \\
\hline Graphium chirnoides & Veined Jay & 2 & Papilionidae & Very rare \\
\hline Graphium agamemnon & Tailed Jay & 9 & Papilionidae & Rare \\
\hline Papilio machaon & Common Yellow Swallowtail & 1 & Papilionidae & Very rare \\
\hline Pseudocoladenia dan & Fulvous Pied Flat & 19 & Hesperiidae & Not rare \\
\hline Tagiades menaka & Spotted snow flat & 8 & Hesperiidae & Rare \\
\hline Tagiades litigiosa & Water Snow Flat & 2 & Hesperiidae & Very rare \\
\hline Notocrypta curvifascia & Restricted Demon & 3 & Hesperiidae & Rare \\
\hline Telicota bambusae & Dark palm Dart & 22 & Hesperiidae & Not rare \\
\hline Parnara guttata & Straight swift & 69 & Hesperiidae & Common \\
\hline Sarangesa dasahara & Common Small Flat & 23 & Hesperiidae & Not rare \\
\hline Iambrix salsala & Chestnut bob & 15 & Hesperiidae & Rare \\
\hline Ochus subvittatus & Tiger hopper & 1 & Hesperiidae & Very rare \\
\hline Spialia galba & Indian skipper & 1 & Hesperiidae & Very rare \\
\hline Catopsilia pomona & Common Emigrant & 12 & Pieridae & Rare \\
\hline Catopsilia pyranthe & Mottled Emigrant & 16 & Pieridae & Not rare \\
\hline Pieris cannida & Indian Cabbage White & 4 & Pieridae & Rare \\
\hline Pieris brassicae & Large Cabbage White & 2 & Pieridae & Very rare \\
\hline Hebomoia glaucippe & Great Orange Tip & 5 & Pieridae & Rare \\
\hline Appias lyncida & Chocolate albatross & 4 & Pieridae & Rare \\
\hline Eurema andersonii & One spot grass yellow & 5 & Pieridae & Rare \\
\hline Eurema blanda & Three-spot-grass Yellow & 29 & Pieridae & Not rare \\
\hline Eurema hecabe & Common Grass Yellow & 38 & Pieridae & Not rare \\
\hline Cepora nadina & Lesser Gull & 14 & Pieridae & Rare \\
\hline Cepora nerissa & Common Gull & 12 & Pieridae & Rare \\
\hline Delias hyparete & Painted jezabel & 5 & Pieridae & Rare \\
\hline Delias acalis & Red Breast jezabel & 1 & Pieridae & Very rare \\
\hline Delias eucharis & Common jezabel & 1 & Pieridae & Very rare \\
\hline Delias descombesi & Red-spot Jezabel & 22 & Pieridae & Not rare \\
\hline Delias pasithoe & Red-Base Jezabel & 5 & Pieridae & Rare \\
\hline Pareronia avatar & Pale wanderer & 2 & Pieridae & Very rare \\
\hline Gandaca harina & Tree yellow & 1 & Pieridae & Very rare \\
\hline Ixias pyrene & Yellow orange tip & 2 & Pieridae & Very rare \\
\hline Belonois aurota & Pioneer & 1 & Pieridae & Very rare \\
\hline Dodona egeon & Orange Punch & 5 & Riodinidae & Rare \\
\hline Abisara neophron & Tailed Judy & 30 & Riodinidae & Not rare \\
\hline Dodona adonira & Striped punch & 5 & Riodinidae & Rare \\
\hline Zemeros flegyas & Punchinello & 92 & Riodinidae & Common \\
\hline Jamides celeno & Common Cerulean & 34 & Lycaenidae & Not rare \\
\hline Jamides alecto & Metallic Cerulean & 30 & Lycaenidae & Not rare \\
\hline Zizina otis & Lesser Grass Blue & 22 & Lycaenidae & Not rare \\
\hline Zizeeria karsandra & Dark Grass Blue & 12 & Lycaenidae & Rare \\
\hline Zizeeria maha & Pale Grass Blue & 10 & Lycaenidae & Rare \\
\hline Arhopala paramuta & Hooked Oakblue & 23 & Lycaenidae & Not rare \\
\hline Jamides bochus & Dark Cerulean & 5 & Lycaenidae & Rare \\
\hline Arhopala amantes & Large Oakblue & 2 & Lycaenidae & Very rare \\
\hline
\end{tabular}




\begin{tabular}{lllll}
\hline Scientific Name & Local Name & Individuals & Family & Butterfly Status \\
\hline Arhopala centaurus & Centaur Oakblue & 1 & Lycaenidae & Very rare \\
Rapala nissa & Common Flash & 20 & Lycaenidae & Not rare \\
Castalius rosimon & Common Pierrot & 7 & Lycaenidae & Rare \\
Tarucus ananda & Dark Pierrot & 8 & Lycaenidae & Rare \\
Curetis bulis & Bright sunbeam & 5 & Lycaenidae & Rare \\
Spindiasis syama & Club silverline & 1 & Lycaenidae & Very rare \\
Spindasis lohita & Long-brand silverline & 2 & Lycaenidae & Very rare \\
Everes lacturnus & Indian Cupid & 9 & Lycaenidae & Rare \\
Prosotas nora & Common lineblue & 15 & Lycaenidae & Rare \\
Prosotas dubiosa & Tailless lineblue & 20 & Lycaenidae & Not rare \\
Heliophorus epicles & Purple Sapphire & 14 & Lycaenidae & Rare \\
Acytolepsis puspa & Common hedge blue & 23 & Lycaenidae & Not rare \\
Lestranicus transpecta & White banded hedge blue & 6 & Lycaenidae & Rare \\
Lampides boeticus & Pea blue & 3 & Lycaenidae & Rare \\
Catochrysops strabo & Forget-me-not blue & 2 & Lycaenidae & Very rare \\
Loxura atymnus & Yamfly & 1 & Lycaenidae & Very rare \\
Zeltus amasa & Fluffy tit & 1 & Lycaenidae & Very rare \\
Rapala pheritima & Copper flash & 24 & Lycaenidae & Not rare \\
Rapala manea & Slate flash & 12 & Lycaenidae & Rare \\
Chliaria othona & Orchid tit & 2 & Lycaenidae & Very rare \\
Anthene emolus & Ciliate Blue & 5 & Lycaenidae & Rare \\
\hline
\end{tabular}

Annex 2: Factors influencing the butterfly to feed in the nectar plants. T= Tubular and NT= Non tubular

\begin{tabular}{|c|c|c|c|c|c|c|c|c|}
\hline S.N & $\begin{array}{l}\text { Butterfly } \\
\text { species }\end{array}$ & $\begin{array}{l}\text { Scientific } \\
\text { Name }\end{array}$ & $\begin{array}{l}\text { Proboscis } \\
\text { length } \\
(\mathrm{mm})\end{array}$ & $\begin{array}{l}\text { Plant } \\
\text { species }\end{array}$ & $\begin{array}{l}\text { Plant } \\
\text { category }\end{array}$ & $\begin{array}{l}\text { Flower } \\
\text { color }\end{array}$ & $\begin{array}{l}\text { Flower } \\
\text { shape }\end{array}$ & $\begin{array}{l}\text { Coroll } \\
\text { length } \\
(\mathrm{mm})\end{array}$ \\
\hline 1 & $\begin{array}{l}\text { Red } \\
\text { Admiral }\end{array}$ & $\begin{array}{l}\text { Vanessa } \\
\text { indica }\end{array}$ & 18.2 & $\begin{array}{l}\text { Lantana } \\
\text { camara }\end{array}$ & woody & yellow & $\mathrm{T}$ & 12 \\
\hline 2 & $\begin{array}{l}\text { Common } \\
\text { tiger }\end{array}$ & $\begin{array}{l}\text { Danaus } \\
\text { genutia }\end{array}$ & 10 & $\begin{array}{l}\text { Eupatorium } \\
\text { odora- } \\
\text { tum }\end{array}$ & woody & purple & $\mathrm{T}$ & 9 \\
\hline 3 & $\begin{array}{l}\text { Glassy } \\
\text { tiger }\end{array}$ & $\begin{array}{l}\text { Parantica } \\
\text { aglea }\end{array}$ & 13 & $\begin{array}{l}\text { Parthenium } \\
\text { hys- } \\
\text { teropho- } \\
\text { rus }\end{array}$ & herb & white & $\mathrm{T}$ & 3 \\
\hline 4 & $\begin{array}{l}\text { Plain } \\
\text { Tiger }\end{array}$ & $\begin{array}{l}\text { Danaus } \\
\text { chrysip- } \\
\text { pus }\end{array}$ & 13 & $\begin{array}{l}\text { Lantana } \\
\text { camara }\end{array}$ & woody & yellow & $\mathrm{T}$ & 12 \\
\hline 5 & $\begin{array}{l}\text { Red } \\
\text { Admiral }\end{array}$ & $\begin{array}{l}\text { Vanessa } \\
\text { indica }\end{array}$ & 18.2 & $\begin{array}{l}\text { Bidens } \\
\text { pilosa }\end{array}$ & herb & white & $\mathrm{T}$ & 5 \\
\hline 6 & $\begin{array}{l}\text { Indian } \\
\text { Fritilary }\end{array}$ & $\begin{array}{l}\text { Argyreus } \\
\text { hyper- } \\
\text { bius }\end{array}$ & 12 & $\begin{array}{l}\text { Zinnia } \\
\text { elegans }\end{array}$ & herb & pink & $\mathrm{T}$ & 2 \\
\hline 7 & $\begin{array}{l}\text { Common } \\
\text { tiger }\end{array}$ & $\begin{array}{l}\text { Danaus } \\
\text { genutia }\end{array}$ & 13 & $\begin{array}{l}\text { Sida } \\
\text { rhambi- } \\
\text { folia }\end{array}$ & herb & yellow & $\mathrm{NT}$ & 3 \\
\hline 8 & $\begin{array}{l}\text { Common } \\
\text { jester }\end{array}$ & $\begin{array}{l}\text { Symbrenthia } \\
\text { lilaea }\end{array}$ & 13 & $\begin{array}{l}\text { Lantana } \\
\text { camara }\end{array}$ & woody & yellow & $\mathrm{T}$ & 12 \\
\hline
\end{tabular}




\begin{tabular}{|c|c|c|c|c|c|c|c|c|}
\hline S.N & $\begin{array}{l}\text { Butterfly } \\
\text { species }\end{array}$ & $\begin{array}{l}\text { Scientific } \\
\text { Name }\end{array}$ & $\begin{array}{l}\text { Proboscis } \\
\text { length } \\
(\mathrm{mm})\end{array}$ & $\begin{array}{l}\text { Plant } \\
\text { species }\end{array}$ & $\begin{array}{l}\text { Plant } \\
\text { category }\end{array}$ & $\begin{array}{l}\text { Flower } \\
\text { color }\end{array}$ & $\begin{array}{l}\text { Flower } \\
\text { shape }\end{array}$ & $\begin{array}{l}\text { Coroll: } \\
\text { length } \\
(\mathrm{mm})\end{array}$ \\
\hline 9 & $\begin{array}{l}\text { Chocolate } \\
\text { Pansy }\end{array}$ & $\begin{array}{l}\text { Junonia } \\
\text { iphita }\end{array}$ & 13 & $\begin{array}{l}\text { Ageratina } \\
\text { adenophora }\end{array}$ & herb & purple & $\mathrm{T}$ & 3 \\
\hline 10 & $\begin{array}{l}\text { Peacock } \\
\text { pansy }\end{array}$ & $\begin{array}{l}\text { Junonia } \\
\text { almana }\end{array}$ & 11.4 & $\begin{array}{l}\text { Lantana } \\
\text { camara }\end{array}$ & woody & yellow & $\mathrm{T}$ & 12 \\
\hline 11 & $\begin{array}{l}\text { Grey } \\
\text { pansy }\end{array}$ & $\begin{array}{l}\text { Junonia } \\
\text { atlites }\end{array}$ & 13 & $\begin{array}{l}\text { Ageratum } \\
\text { cony- } \\
\text { zoides }\end{array}$ & herb & white & $\mathrm{T}$ & 3 \\
\hline 12 & $\begin{array}{l}\text { Grey } \\
\text { pansy }\end{array}$ & $\begin{array}{l}\text { Junonia } \\
\text { atlites }\end{array}$ & 13 & $\begin{array}{l}\text { Ageratum } \\
\text { housto- } \\
\text { nianum }\end{array}$ & herb & blue & $\mathrm{T}$ & 4 \\
\hline 13 & $\begin{array}{l}\text { Lemon } \\
\text { pansy }\end{array}$ & $\begin{array}{l}\text { Junonia } \\
\text { lemo- } \\
\text { nias }\end{array}$ & 12 & $\begin{array}{l}\text { Bidens } \\
\text { pilosa }\end{array}$ & herb & white & $\mathrm{T}$ & 5 \\
\hline 14 & $\begin{array}{l}\text { Common } \\
\text { tiger }\end{array}$ & $\begin{array}{l}\text { Danaus } \\
\text { genutia }\end{array}$ & 8 & $\begin{array}{l}\text { Lantana } \\
\text { camara }\end{array}$ & woody & yellow & $\mathrm{T}$ & 12 \\
\hline 15 & $\begin{array}{l}\text { Striped } \\
\text { blue } \\
\text { crow }\end{array}$ & $\begin{array}{l}\text { Euploea } \\
\text { mul- } \\
\text { ciber }\end{array}$ & 9.3 & $\begin{array}{l}\text { Eupatorium } \\
\text { odora- } \\
\text { tum }\end{array}$ & herb & purple & $\mathrm{T}$ & 9 \\
\hline 16 & $\begin{array}{l}\text { Common } \\
\text { indian } \\
\text { crow }\end{array}$ & $\begin{array}{l}\text { Euploea } \\
\text { core }\end{array}$ & 12 & $\begin{array}{l}\text { Ageratum } \\
\text { housto- } \\
\text { nianum }\end{array}$ & herb & blue & $\mathrm{T}$ & 4 \\
\hline 17 & $\begin{array}{l}\text { Common } \\
\text { indian } \\
\text { crow }\end{array}$ & $\begin{array}{l}\text { Euploea } \\
\text { core }\end{array}$ & 12 & $\begin{array}{l}\text { Tagetes } \\
\text { erecta }\end{array}$ & herb & yellow & $\mathrm{T}$ & 17 \\
\hline 18 & $\begin{array}{l}\text { Common } \\
\text { sailor }\end{array}$ & $\begin{array}{l}\text { Neptis } \\
\text { hylas }\end{array}$ & 7 & $\begin{array}{l}\text { Ageratina } \\
\text { adenophora }\end{array}$ & herb & purple & $\mathrm{T}$ & 3 \\
\hline 19 & $\begin{array}{l}\text { Common } \\
\text { tiger }\end{array}$ & $\begin{array}{l}\text { Danaus } \\
\text { genutia }\end{array}$ & 10 & $\begin{array}{l}\text { Ageratum } \\
\text { housto- } \\
\text { nianum }\end{array}$ & herb & blue & $\mathrm{T}$ & 4 \\
\hline 20 & $\begin{array}{l}\text { Glassy } \\
\text { tiger }\end{array}$ & $\begin{array}{l}\text { Parantica } \\
\text { aglea }\end{array}$ & 13 & $\begin{array}{l}\text { Bidens } \\
\text { pilosa }\end{array}$ & herb & white & $\mathrm{T}$ & 5 \\
\hline 21 & $\begin{array}{l}\text { Glassy } \\
\text { tiger }\end{array}$ & $\begin{array}{l}\text { Parantica } \\
\text { aglea }\end{array}$ & 13 & $\begin{array}{l}\text { Ageratum } \\
\text { housto- } \\
\text { nianum }\end{array}$ & herb & blue & $\mathrm{T}$ & 4 \\
\hline 22 & $\begin{array}{l}\text { Plain } \\
\text { Tiger }\end{array}$ & $\begin{array}{l}\text { Danaus } \\
\text { chrysip- } \\
\text { pus }\end{array}$ & 13 & $\begin{array}{l}\text { Bidens } \\
\text { pilosa }\end{array}$ & herb & white & $\mathrm{T}$ & 5 \\
\hline 23 & $\begin{array}{l}\text { Common } \\
\text { five ring }\end{array}$ & $\begin{array}{l}\text { Ypthima } \\
\text { baldus }\end{array}$ & 5.1 & $\begin{array}{l}\text { Borreria } \\
\text { latifolia }\end{array}$ & herb & purple & $\mathrm{T}$ & 4 \\
\hline 24 & $\begin{array}{l}\text { Peacock } \\
\text { pansy }\end{array}$ & $\begin{array}{l}\text { Junonia } \\
\text { almana }\end{array}$ & 11.4 & $\begin{array}{l}\text { Eupatorium } \\
\text { odora- } \\
\text { tum }\end{array}$ & woody & purple & $\mathrm{T}$ & 9 \\
\hline 25 & $\begin{array}{l}\text { Plain } \\
\text { Tiger }\end{array}$ & $\begin{array}{l}\text { Danaus } \\
\text { chrysip- } \\
\text { pus }\end{array}$ & 11 & $\begin{array}{l}\text { Ageratum } \\
\text { housto- } \\
\text { nianum }\end{array}$ & herb & purple & $\mathrm{T}$ & 4 \\
\hline 26 & $\begin{array}{l}\text { Striped } \\
\text { blue } \\
\text { crow }\end{array}$ & $\begin{array}{l}\text { Euploea } \\
\text { mul- } \\
\text { ciber }\end{array}$ & 9.3 & $\begin{array}{l}\text { Ageratum } \\
\text { housto- } \\
\text { nianum }\end{array}$ & herb & purple & $\mathrm{T}$ & 4 \\
\hline
\end{tabular}




\begin{tabular}{|c|c|c|c|c|c|c|c|c|}
\hline S.N & $\begin{array}{l}\text { Butterfly } \\
\text { species }\end{array}$ & $\begin{array}{l}\text { Scientific } \\
\text { Name }\end{array}$ & $\begin{array}{l}\text { Proboscis } \\
\text { length } \\
(\mathrm{mm})\end{array}$ & $\begin{array}{l}\text { Plant } \\
\text { species }\end{array}$ & $\begin{array}{l}\text { Plant } \\
\text { category }\end{array}$ & $\begin{array}{l}\text { Flower } \\
\text { color }\end{array}$ & $\begin{array}{l}\text { Flower } \\
\text { shape }\end{array}$ & $\begin{array}{l}\text { Coroll } \\
\text { length } \\
(\mathrm{mm})\end{array}$ \\
\hline 27 & $\begin{array}{l}\text { Common } \\
\text { indian } \\
\text { crow }\end{array}$ & $\begin{array}{l}\text { Euploea } \\
\text { core }\end{array}$ & 12 & $\begin{array}{l}\text { Bidens } \\
\text { pilosa }\end{array}$ & herb & white & $\mathrm{T}$ & 5 \\
\hline 28 & $\begin{array}{l}\text { Common } \\
\text { indian } \\
\text { crow }\end{array}$ & $\begin{array}{l}\text { Euploea } \\
\text { core }\end{array}$ & 12 & $\begin{array}{l}\text { Zinnia } \\
\text { elegans }\end{array}$ & herb & pink & $\mathrm{T}$ & 6 \\
\hline 29 & $\begin{array}{l}\text { Common } \\
\text { five ring }\end{array}$ & $\begin{array}{l}\text { Ypthima } \\
\text { baldus }\end{array}$ & 5.1 & $\begin{array}{l}\text { Bidens } \\
\text { pilosa }\end{array}$ & herb & white & $\mathrm{T}$ & 5 \\
\hline 30 & $\begin{array}{l}\text { Lemon } \\
\text { pansy }\end{array}$ & $\begin{array}{l}\text { Junonia } \\
\text { lemo- } \\
\text { nias }\end{array}$ & 12 & $\begin{array}{l}\text { Cuphea } \\
\text { hyssopi- } \\
\text { folia }\end{array}$ & woody & purple & $\mathrm{T}$ & 8 \\
\hline 31 & $\begin{array}{l}\text { Lemon } \\
\text { pansy }\end{array}$ & $\begin{array}{l}\text { Junonia } \\
\text { lemo- } \\
\text { nias }\end{array}$ & 12 & $\begin{array}{l}\text { Lantana } \\
\text { camara }\end{array}$ & woody & yellow & $\mathrm{T}$ & 12 \\
\hline 32 & $\begin{array}{l}\text { Lemon } \\
\text { pansy }\end{array}$ & $\begin{array}{l}\text { Junonia } \\
\text { lemo- } \\
\text { nias }\end{array}$ & 12 & $\begin{array}{l}\text { Eupatorium } \\
\text { odora- } \\
\text { tum }\end{array}$ & herb & purple & $\mathrm{T}$ & 9 \\
\hline 33 & $\begin{array}{l}\text { Club } \\
\text { silverline }\end{array}$ & $\begin{array}{l}\text { Spindiasis } \\
\text { syama }\end{array}$ & 8 & $\begin{array}{l}\text { Eupatorium } \\
\text { odora- } \\
\text { tum }\end{array}$ & woody & purple & $\mathrm{T}$ & 9 \\
\hline 34 & $\begin{array}{l}\text { Common } \\
\text { cerulian }\end{array}$ & $\begin{array}{l}\text { Jamides } \\
\text { celeno }\end{array}$ & 6.1 & $\begin{array}{l}\text { Vitex } \\
\text { negundo }\end{array}$ & woody & purple & $\mathrm{T}$ & 5 \\
\hline 35 & $\begin{array}{l}\text { Copper } \\
\text { flash }\end{array}$ & $\begin{array}{l}\text { Rapala } \\
\text { pher- } \\
\text { itima }\end{array}$ & 9 & $\begin{array}{l}\text { Eupatorium } \\
\text { odora- } \\
\text { tum }\end{array}$ & woody & purple & $\mathrm{T}$ & 9 \\
\hline 36 & $\begin{array}{l}\text { Copper } \\
\text { flash }\end{array}$ & $\begin{array}{l}\text { Rapala } \\
\text { pher- } \\
\text { itima }\end{array}$ & 9 & $\begin{array}{l}\text { Bidens } \\
\text { pilosa }\end{array}$ & herb & white & $\mathrm{T}$ & 5 \\
\hline 37 & Pea blue & $\begin{array}{l}\text { Lampides } \\
\text { boeticus }\end{array}$ & 7 & $\begin{array}{l}\text { Tridax } \\
\text { procum- } \\
\text { bens }\end{array}$ & herb & white & $\mathrm{T}$ & 8 \\
\hline 38 & $\begin{array}{l}\text { Club } \\
\text { silverline }\end{array}$ & $\begin{array}{l}\text { Spindiasis } \\
\text { syama }\end{array}$ & 8 & $\begin{array}{l}\text { Lantana } \\
\text { camara }\end{array}$ & woody & yellow & $\mathrm{T}$ & 12 \\
\hline 39 & $\begin{array}{l}\text { Common } \\
\text { pierrot }\end{array}$ & $\begin{array}{l}\text { Castalius } \\
\text { rosimon }\end{array}$ & 8 & $\begin{array}{l}\text { Sida } \\
\text { rhambi- } \\
\text { folia }\end{array}$ & herb & yellow & $\mathrm{NT}$ & 3 \\
\hline 40 & $\begin{array}{l}\text { Indian } \\
\text { cupid }\end{array}$ & $\begin{array}{l}\text { Everes } \\
\text { lactur- } \\
\text { nus }\end{array}$ & 4 & $\begin{array}{l}\text { Bidens } \\
\text { pilosa }\end{array}$ & herb & white & $\mathrm{T}$ & 5 \\
\hline 41 & $\begin{array}{l}\text { Indian } \\
\text { cupid }\end{array}$ & $\begin{array}{l}\text { Everes } \\
\text { lactur- } \\
\text { nus }\end{array}$ & 4 & $\begin{array}{l}\text { Desmodium } \\
\text { confer- } \\
\text { tum }\end{array}$ & herb & purple & $\mathrm{T}$ & 4 \\
\hline 42 & Pea blue & $\begin{array}{l}\text { Lampides } \\
\text { boeticus }\end{array}$ & 7 & $\begin{array}{l}\text { Duranta } \\
\text { erecta }\end{array}$ & woody & purple & $\mathrm{T}$ & 7 \\
\hline 43 & $\begin{array}{l}\text { Common } \\
\text { pierrot }\end{array}$ & $\begin{array}{l}\text { Castalius } \\
\text { rosimon }\end{array}$ & 8 & $\begin{array}{l}\text { Bidens } \\
\text { pilosa }\end{array}$ & herb & white & $\mathrm{T}$ & 5 \\
\hline
\end{tabular}




\begin{tabular}{|c|c|c|c|c|c|c|c|c|}
\hline S.N & $\begin{array}{l}\text { Butterfly } \\
\text { species }\end{array}$ & $\begin{array}{l}\text { Scientific } \\
\text { Name }\end{array}$ & $\begin{array}{l}\text { Proboscis } \\
\text { length } \\
(\mathrm{mm})\end{array}$ & $\begin{array}{l}\text { Plant } \\
\text { species }\end{array}$ & $\begin{array}{l}\text { Plant } \\
\text { category }\end{array}$ & $\begin{array}{l}\text { Flower } \\
\text { color }\end{array}$ & $\begin{array}{l}\text { Flower } \\
\text { shape }\end{array}$ & $\begin{array}{l}\text { Coroll } \\
\text { length } \\
(\mathrm{mm})\end{array}$ \\
\hline 44 & $\begin{array}{l}\text { Great } \\
\text { Mormon }\end{array}$ & $\begin{array}{l}\text { Papilio } \\
\text { mem- } \\
\text { non }\end{array}$ & 34 & $\begin{array}{l}\text { Eupatorium } \\
\text { odora- } \\
\text { tum }\end{array}$ & woody & purple & $\mathrm{T}$ & 9 \\
\hline 45 & $\begin{array}{l}\text { Common } \\
\text { mime }\end{array}$ & $\begin{array}{l}\text { Chilasa } \\
\text { clytia }\end{array}$ & 14 & $\begin{array}{l}\text { Lantana } \\
\text { camara }\end{array}$ & woody & yellow & $\mathrm{T}$ & 12 \\
\hline 46 & $\begin{array}{l}\text { Common } \\
\text { mormon }\end{array}$ & $\begin{array}{l}\text { Papilio } \\
\text { polytes }\end{array}$ & 25 & $\begin{array}{l}\text { Ipomoea } \\
\text { quamo- } \\
\text { clit }\end{array}$ & herb & pink & $\mathrm{T}$ & 26 \\
\hline 47 & $\begin{array}{l}\text { Common } \\
\text { mormon }\end{array}$ & $\begin{array}{l}\text { Papilio } \\
\text { polytes }\end{array}$ & 25 & $\begin{array}{l}\text { Mussaenda } \\
\text { rox- } \\
\text { burghii }\end{array}$ & woody & yellow & $\mathrm{T}$ & 28 \\
\hline 48 & Spangle & $\begin{array}{l}\text { Papilio } \\
\text { pro- } \\
\text { tenor }\end{array}$ & 32 & $\begin{array}{l}\text { Salvia } \\
\text { coccinea }\end{array}$ & herb & red & $\mathrm{T}$ & 29 \\
\hline 49 & $\begin{array}{l}\text { Common } \\
\text { mormon }\end{array}$ & $\begin{array}{l}\text { Papilio } \\
\text { polytes }\end{array}$ & 25 & $\begin{array}{l}\text { Lantana } \\
\text { camara }\end{array}$ & woody & yellow & $\mathrm{T}$ & 12 \\
\hline 50 & $\begin{array}{l}\text { Common } \\
\text { mormon }\end{array}$ & $\begin{array}{l}\text { Papilio } \\
\text { polytes }\end{array}$ & 25 & $\begin{array}{l}\text { Bougainvillea } \\
\text { glabra }\end{array}$ & woody & pink & $\mathrm{T}$ & 20 \\
\hline 51 & $\begin{array}{l}\text { Mottled } \\
\text { Emigrant }\end{array}$ & $\begin{array}{l}\text { Catopsilia } \\
\text { pyran- } \\
\text { the }\end{array}$ & 16 & $\begin{array}{l}\text { Bidens } \\
\text { pilosa }\end{array}$ & herb & white & $\mathrm{T}$ & 5 \\
\hline 52 & $\begin{array}{l}\text { Mottled } \\
\text { Emigrant }\end{array}$ & $\begin{array}{l}\text { Catopsilia } \\
\text { pyran- } \\
\text { the }\end{array}$ & 16 & $\begin{array}{l}\text { Zinnia } \\
\text { elegans }\end{array}$ & herb & pink & $\mathrm{T}$ & 2 \\
\hline 53 & $\begin{array}{l}\text { Common } \\
\text { grass } \\
\text { yellow }\end{array}$ & $\begin{array}{l}\text { Eurema } \\
\text { hecabe }\end{array}$ & 15 & $\begin{array}{l}\text { Parthenium } \\
\text { hys- } \\
\text { teropho- } \\
\text { rus }\end{array}$ & herb & white & $\mathrm{T}$ & 3 \\
\hline 54 & $\begin{array}{l}\text { Red } \\
\text { spot } \\
\text { jezeble }\end{array}$ & $\begin{array}{l}\text { Delias } \\
\text { de- } \\
\text { scombesi }\end{array}$ & 16 & $\begin{array}{l}\text { Sambucus } \\
\text { adnata }\end{array}$ & herb & white & $\mathrm{NT}$ & 4 \\
\hline 55 & $\begin{array}{l}\text { Chocolate } \\
\text { Albatross }\end{array}$ & $\begin{array}{l}\text { Appias } \\
\text { lyncida }\end{array}$ & 14 & $\begin{array}{l}\text { Bidens } \\
\text { pilosa }\end{array}$ & herb & white & $\mathrm{T}$ & 5 \\
\hline 56 & $\begin{array}{l}\text { Mottled } \\
\text { Emigrant }\end{array}$ & $\begin{array}{l}\text { Catopsilia } \\
\text { pyran- } \\
\text { the }\end{array}$ & 16 & $\begin{array}{l}\text { Eupatorium } \\
\text { odora- } \\
\text { tum }\end{array}$ & woody & purple & $\mathrm{T}$ & 9 \\
\hline 57 & $\begin{array}{l}\text { Chocolate } \\
\text { Albatross }\end{array}$ & $\begin{array}{l}\text { Appias } \\
\text { lyncida }\end{array}$ & 14 & $\begin{array}{l}\text { Sambucus } \\
\text { wight- } \\
\text { iana }\end{array}$ & herb & white & NT & 4 \\
\hline 58 & $\begin{array}{l}\text { Common } \\
\text { grass } \\
\text { yellow }\end{array}$ & $\begin{array}{l}\text { Eurema } \\
\text { hecabe }\end{array}$ & 15 & $\begin{array}{l}\text { Borreria } \\
\text { latifolia }\end{array}$ & herb & purple & $\mathrm{T}$ & 4 \\
\hline 59 & $\begin{array}{l}\text { Common } \\
\text { grass } \\
\text { yellow }\end{array}$ & $\begin{array}{l}\text { Eurema } \\
\text { hecabe }\end{array}$ & 15 & $\begin{array}{l}\text { Eupatorium } \\
\text { odora- } \\
\text { tum }\end{array}$ & woody & purple & $\mathrm{T}$ & 9 \\
\hline 60 & $\begin{array}{l}\text { Mottled } \\
\text { Emigrant }\end{array}$ & $\begin{array}{l}\text { Catopsilia } \\
\text { pyran- } \\
\text { the }\end{array}$ & 16 & $\begin{array}{l}\text { Bidens } \\
\text { pilosa }\end{array}$ & herb & white & $\mathrm{T}$ & 5 \\
\hline
\end{tabular}




\begin{tabular}{|c|c|c|c|c|c|c|c|c|}
\hline S.N & $\begin{array}{l}\text { Butterfly } \\
\text { species }\end{array}$ & $\begin{array}{l}\text { Scientific } \\
\text { Name }\end{array}$ & $\begin{array}{l}\text { Proboscis } \\
\text { length } \\
(\mathrm{mm})\end{array}$ & $\begin{array}{l}\text { Plant } \\
\text { species }\end{array}$ & $\begin{array}{l}\text { Plant } \\
\text { category }\end{array}$ & $\begin{array}{l}\text { Flower } \\
\text { color }\end{array}$ & $\begin{array}{l}\text { Flower } \\
\text { shape }\end{array}$ & $\begin{array}{l}\text { Coroll } \\
\text { length } \\
(\mathrm{mm})\end{array}$ \\
\hline 61 & $\begin{array}{l}\text { Common } \\
\text { grass } \\
\text { yellow }\end{array}$ & $\begin{array}{l}\text { Eurema } \\
\text { hecabe }\end{array}$ & 15 & $\begin{array}{l}\text { Sida } \\
\text { rhambi- } \\
\text { folia }\end{array}$ & herb & yellow & $\mathrm{NT}$ & 3 \\
\hline 62 & $\begin{array}{l}\text { Red } \\
\text { spot } \\
\text { jezeble }\end{array}$ & $\begin{array}{l}\text { Delias } \\
\text { de- } \\
\text { scombesi }\end{array}$ & 16 & $\begin{array}{l}\text { Eupatorium } \\
\text { odora- } \\
\text { tum }\end{array}$ & herb & purple & $\mathrm{T}$ & 9 \\
\hline 63 & $\begin{array}{l}\text { Red } \\
\text { spot } \\
\text { jezeble }\end{array}$ & $\begin{array}{l}\text { Delias } \\
\text { de- } \\
\text { scombesi }\end{array}$ & 16 & $\begin{array}{l}\text { Castanopsis } \\
\text { indica }\end{array}$ & woody & white & $\mathrm{NT}$ & 4 \\
\hline 64 & $\begin{array}{l}\text { Common } \\
\text { grass } \\
\text { yellow }\end{array}$ & $\begin{array}{l}\text { Eurema } \\
\text { hecabe }\end{array}$ & 15 & $\begin{array}{l}\text { Tagetes } \\
\text { erecta }\end{array}$ & herb & yellow & $\mathrm{T}$ & 17 \\
\hline 65 & $\begin{array}{l}\text { Mottled } \\
\text { Emigrant }\end{array}$ & $\begin{array}{l}\text { Catopsilia } \\
\text { pyran- } \\
\text { the }\end{array}$ & 16 & $\begin{array}{l}\text { Zinnia } \\
\text { elegans }\end{array}$ & herb & yellow & $\mathrm{T}$ & 6 \\
\hline 66 & $\begin{array}{l}\text { Chocolate } \\
\text { Albatross }\end{array}$ & $\begin{array}{l}\text { Appias } \\
\text { lyncida }\end{array}$ & 14 & $\begin{array}{l}\text { Eupatorium } \\
\text { odora- } \\
\text { tum }\end{array}$ & herb & purple & $\mathrm{T}$ & 9 \\
\hline 67 & $\begin{array}{l}\text { Chocolate } \\
\text { Albatross }\end{array}$ & $\begin{array}{l}\text { Appias } \\
\text { lyncida }\end{array}$ & 14 & $\begin{array}{l}\text { Lantana } \\
\text { camara }\end{array}$ & woody & yellow & $\mathrm{T}$ & 12 \\
\hline 68 & $\begin{array}{l}\text { Straight } \\
\text { Swift }\end{array}$ & $\begin{array}{l}\text { Parnara } \\
\text { guttata }\end{array}$ & 17 & $\begin{array}{l}\text { Sida } \\
\text { rhambi- } \\
\text { folia }\end{array}$ & herb & yellow & $\mathrm{NT}$ & 3 \\
\hline 69 & $\begin{array}{l}\text { Straight } \\
\text { Swift }\end{array}$ & $\begin{array}{l}\text { Parnara } \\
\text { guttata }\end{array}$ & 17 & $\begin{array}{l}\text { Borreria } \\
\text { latifolia }\end{array}$ & herb & purple & $\mathrm{T}$ & 4 \\
\hline 70 & $\begin{array}{l}\text { Common } \\
\text { small } \\
\text { flat }\end{array}$ & $\begin{array}{l}\text { Sarangesa } \\
\text { dasa- } \\
\text { hara }\end{array}$ & 12 & $\begin{array}{l}\text { Parthenium } \\
\text { hys- } \\
\text { teropho- } \\
\text { rus }\end{array}$ & herb & white & $\mathrm{T}$ & 3 \\
\hline 71 & $\begin{array}{l}\text { Himalayan } \\
\text { spotted } \\
\text { flat }\end{array}$ & $\begin{array}{l}\text { Celaenorr } \\
\text { munda }\end{array}$ & & $\begin{array}{l}\text { Urena } \\
\text { lobata }\end{array}$ & herb & pink & $\mathrm{NT}$ & 12 \\
\hline 72 & $\begin{array}{l}\text { Straight } \\
\text { Swift }\end{array}$ & $\begin{array}{l}\text { Parnara } \\
\text { guttata }\end{array}$ & 17 & $\begin{array}{l}\text { Bidens } \\
\text { pilosa }\end{array}$ & herb & white & $\mathrm{T}$ & 5 \\
\hline 73 & $\begin{array}{l}\text { Straight } \\
\text { Swift }\end{array}$ & $\begin{array}{l}\text { Parnara } \\
\text { guttata }\end{array}$ & 17 & $\begin{array}{l}\text { Ageratum } \\
\text { cony- } \\
\text { zoides }\end{array}$ & herb & white & $\mathrm{T}$ & 3 \\
\hline 74 & $\begin{array}{l}\text { Common } \\
\text { small } \\
\text { flat }\end{array}$ & $\begin{array}{l}\text { Sarangesa } \\
\text { dasa- } \\
\text { hara }\end{array}$ & 12 & $\begin{array}{l}\text { Borreria } \\
\text { latifolia }\end{array}$ & herb & purple & $\mathrm{T}$ & 4 \\
\hline 75 & $\begin{array}{l}\text { Straight } \\
\text { Swift }\end{array}$ & $\begin{array}{l}\text { Parnara } \\
\text { guttata }\end{array}$ & 17 & $\begin{array}{l}\text { Coreopsis } \\
\text { lanceo- } \\
\text { lata }\end{array}$ & herb & yellow & $\mathrm{T}$ & 4 \\
\hline 76 & $\begin{array}{l}\text { Straight } \\
\text { Swift }\end{array}$ & $\begin{array}{l}\text { Parnara } \\
\text { guttata }\end{array}$ & 17 & $\begin{array}{l}\text { Cosmic } \\
\text { sul- } \\
\text { phureus }\end{array}$ & herb & yellow & $\mathrm{T}$ & 3 \\
\hline 77 & $\begin{array}{l}\text { Straight } \\
\text { Swift }\end{array}$ & $\begin{array}{l}\text { Parnara } \\
\text { guttata }\end{array}$ & 17 & $\begin{array}{l}\text { Mimosa } \\
\text { pudica }\end{array}$ & herb & purple & $\mathrm{NT}$ & 2 \\
\hline
\end{tabular}




\begin{tabular}{|c|c|c|c|c|c|c|c|c|}
\hline S.N & $\begin{array}{l}\text { Butterfly } \\
\text { species }\end{array}$ & $\begin{array}{l}\text { Scientific } \\
\text { Name }\end{array}$ & $\begin{array}{l}\text { Proboscis } \\
\text { length } \\
(\mathrm{mm})\end{array}$ & $\begin{array}{l}\text { Plant } \\
\text { species }\end{array}$ & $\begin{array}{l}\text { Plant } \\
\text { category }\end{array}$ & $\begin{array}{l}\text { Flower } \\
\text { color }\end{array}$ & $\begin{array}{l}\text { Flower } \\
\text { shape }\end{array}$ & $\begin{array}{l}\text { Coroll } \\
\text { length } \\
(\mathrm{mm})\end{array}$ \\
\hline 78 & $\begin{array}{l}\text { Straight } \\
\text { Swift }\end{array}$ & $\begin{array}{l}\text { Parnara } \\
\text { guttata }\end{array}$ & 17 & $\begin{array}{l}\text { Cosmic } \\
\text { sul- } \\
\text { phureus }\end{array}$ & herb & yellow & $\mathrm{T}$ & 3 \\
\hline 79 & $\begin{array}{l}\text { Straight } \\
\text { Swift }\end{array}$ & $\begin{array}{l}\text { Parnara } \\
\text { guttata }\end{array}$ & 17 & $\begin{array}{l}\text { Acmella } \\
\text { uligi- } \\
\text { nosa }\end{array}$ & herb & yellow & $\mathrm{T}$ & 4 \\
\hline 80 & $\begin{array}{l}\text { Straight } \\
\text { Swift }\end{array}$ & $\begin{array}{l}\text { Parnara } \\
\text { guttata }\end{array}$ & 17 & $\begin{array}{l}\text { Duranta } \\
\text { erecta }\end{array}$ & woody & purple & $\mathrm{T}$ & 7 \\
\hline
\end{tabular}

Annex 3. Descriptive statistics (by family) for butterfly proboscis length (in mm) and corolla tube length (in $\mathrm{mm}$ ) of flowers visited by butterflies

\begin{tabular}{|c|c|c|c|c|c|c|c|}
\hline & Family & Number & Mean & $\begin{array}{l}\text { Standard } \\
\text { deviation }\end{array}$ & Median & $\begin{array}{l}\text { Inter } \\
\text { quartile } \\
\text { range }\end{array}$ & Range \\
\hline \multirow{5}{*}{$\begin{array}{l}\text { Proboscis } \\
\text { length } \\
(\mathrm{mm})\end{array}$} & Hesperidae & 13 & 16.46 & 2.15 & 17 & 0 & $12-20$ \\
\hline & Nymphalidae & 32 & 11.63 & 2.80 & 12 & 2.25 & $5.1-18.2$ \\
\hline & Pieridae & 16 & 15.18 & 0.83 & 15 & 1.25 & $14-16$ \\
\hline & Lycaenidae & 11 & 7.10 & 1.75 & 8 & 1.45 & $4-9$ \\
\hline & Papilionidae & 7 & 25.71 & 6.42 & 25 & 3.5 & $14-34$ \\
\hline \multirow{5}{*}{$\begin{array}{l}\text { Corolla } \\
\text { tube } \\
\text { length } \\
(\mathrm{mm})\end{array}$} & Hesperidae & 13 & 4.38 & 2.60 & 4 & 1 & $2-12$ \\
\hline & Nymphalidae & 32 & 6.69 & 3.84 & 5 & 5 & $2-17$ \\
\hline & Pieridae & 16 & 6.63 & 3.96 & 5 & 5 & $2-17$ \\
\hline & Lycaenidae & 11 & 6.55 & 2.70 & 5 & 3.5 & $3-12$ \\
\hline & $\begin{array}{l}\text { Papilioni } \\
\text { dae }\end{array}$ & 7 & 19.43 & 8.44 & 20 & 15 & $9-29$ \\
\hline
\end{tabular}

Annex 4. Photoes of butterflies species observed in Rupa Lake. a. Vanessa indica feeding on Lantana Camara b. Argynnis hyperbius on Zinnia elegans c.Danaus genutia on Sida rhambifolia d. Junonia iphita on Ageratum adenophora e. Junonia almana on Lantana camara f. Junonia lemonias on Bidens pilosa g. Euploea mulciber on Ageratum conyzoides h. Euploea core on Ageratum conyzoides I. Euploea core on Zinnia elegans j. Parantica aglea in Ageratum conyzoides k. Spindasis lohita on Lantana camara l. Danaus chrysippus on Bidens pilosa m. Junonia almana on Lantana Camara n. Danaus chrysippus on Ageratum conyzoides o. Junonia lemonias on Lantana camara p. Delias pasithoe on Eupatorium odoratumq. Danaus genutia on Ageratum conyzoides r. Junonia lemonias on Cuphea hyssopifolia s. Vanessa cardui on Ageratum adenophora t. Eurema andersoni on Urena Lobatau. Delias descombesi on Lantana Camara v. Everes lacturnu s on Desmodium confertum w. Catopsilia pomona on Zinnia elegans x. Tagaides litigiosa on Lantana camara y. Papilio memon on Eupatorium odoratum z. Papilio protenor on Salvia Coccinea 
